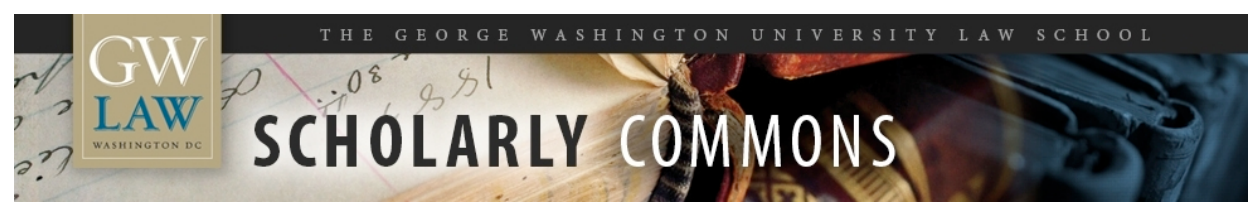

\title{
Identifying Anticompetitive Agreements in the United States and the European Union: Developing a Coherent Antitrust Analytical Framework
}

William E. Kovacic

George Washington University Law School, wkovacic@law.gwu.edu

Follow this and additional works at: https://scholarship.law.gwu.edu/faculty_publications

Part of the Law Commons

\section{Recommended Citation}

Jones, Alison and Kovacic, William E., Identifying Anticompetitive Agreements in the United States and the European Union: Developing a Coherent Antitrust Analytical Framework (February 17, 2017). Antitrust Bulletin, Forthcoming; GWU Law School Public Law Research Paper No. 2017-12; GWU Legal Studies Research Paper No. 2017-12. Available at SSRN: https://ssrn.com/abstract=2919312 or http://dx.doi.org/ $10.2139 /$ ssrn.2919312

This Article is brought to you for free and open access by the Faculty Scholarship at Scholarly Commons. It has been accepted for inclusion in GW Law Faculty Publications \& Other Works by an authorized administrator of Scholarly Commons. For more information, please contact spagel@law.gwu.edu. 


\title{
Identifying Anticompetitive Agreements in the United States and the European Union: Developing a Coherent Antitrust Analytical Framework
}

\author{
Alison Jones \& William E. Kovacic* \\ This is a pre-publication version of an article to be published in the Antitrust Bulletin
}

\section{Contents}

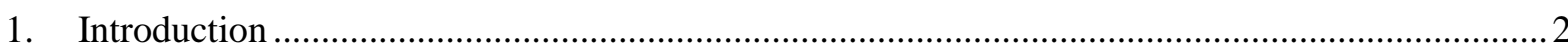

2. Developing a coherent framework: The Design of Legal Commands .........................................5

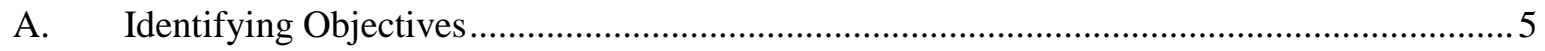

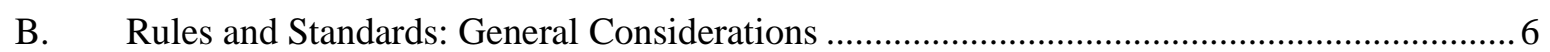

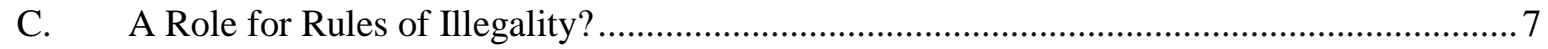

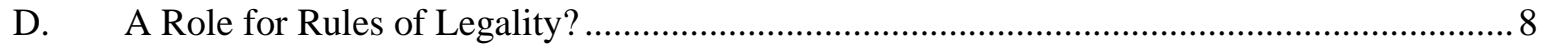

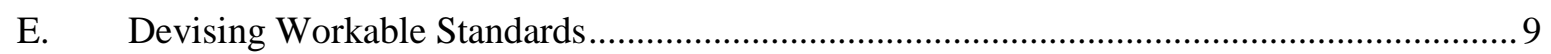

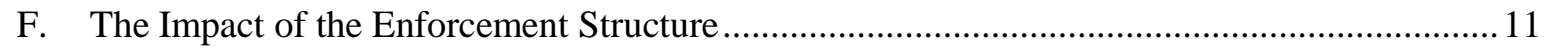

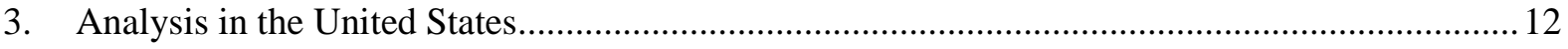

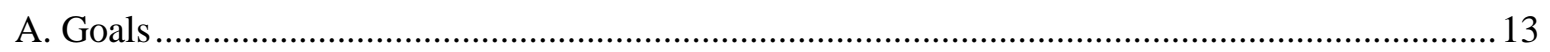

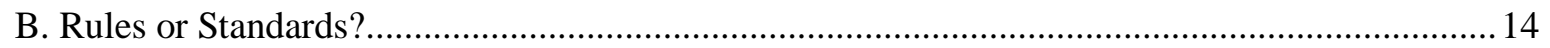

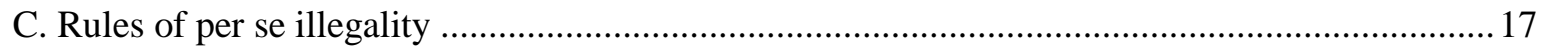

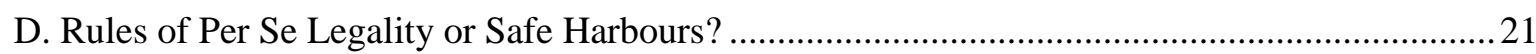

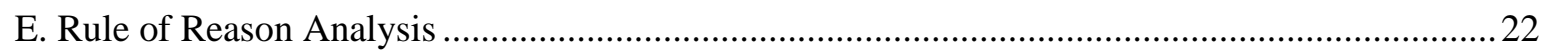

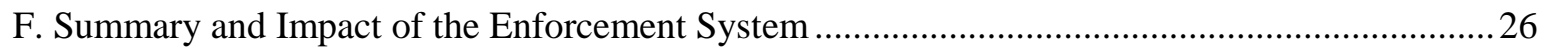

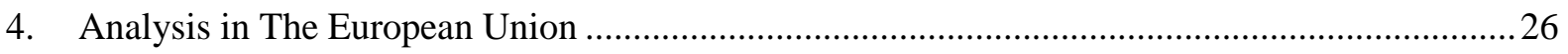

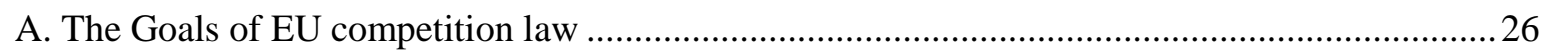

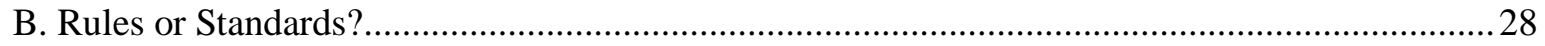

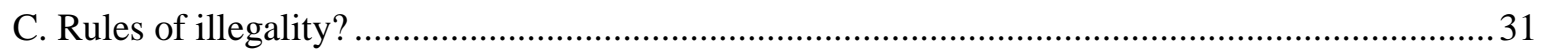

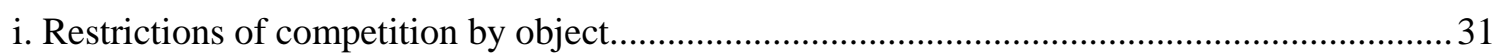

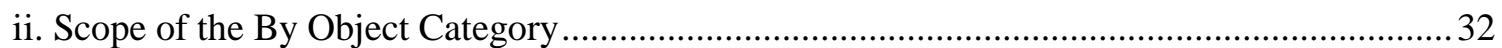

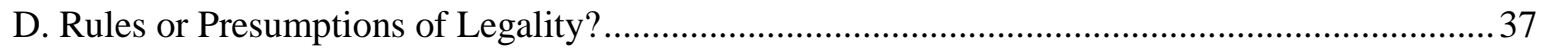

E. Developing Standards: Individual "Effects" Analysis under Article 101(1) and Article

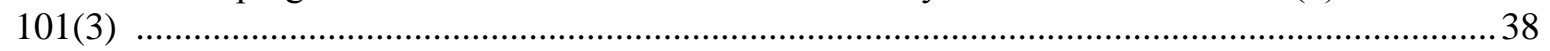

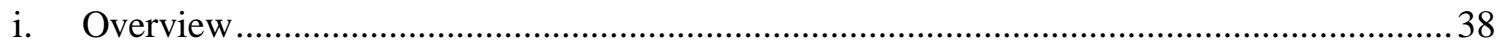

ii. Article 101(1) - identifying agreements with restrictive effects............................................. 38

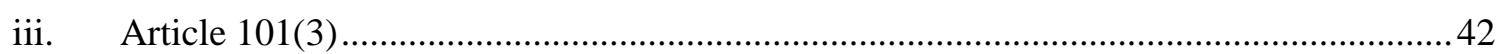

F. Summary and the Impact of the Enforcement System......................................................... 43

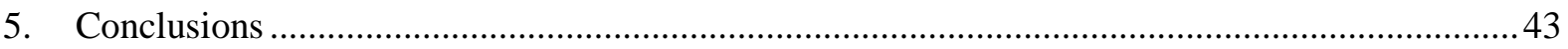

Alison Jones, alison.jones@kcl.ac.uk, is a Professor of Law at King’s College London. William E Kovacic, wkovacic@law.gwu.edu, is Professor of Global Competition Law and Policy at George Washington University, Visiting Professor at King's College London, and Non-Executive Director, United Kingdom Competition and Markets Authority. 


\section{INTRODUCTION}

Since the late 1980s, competition law has become a truly global regulatory enterprise. More than 130 jurisdictions around the world now have competition (or antitrust) systems in place. ${ }^{1}$ Many of these, to prevent firms from distorting competition, stand upon three main substantive pillars:

(i) provisions prohibiting restrictive agreements (in the US and EU, Section One of the Sherman Act $1890^{2}$ and Article $101^{3}$ of the Treaty on the Functioning of the European Union ("TFEU") respectively);

(ii) provisions prohibiting monopolization (or attempts to monopolize) or abusive conduct of dominant firms (Section Two Sherman Act and Article 102 TFEU ) ${ }^{4}$ and

(iii) provisions prohibiting mergers that will substantially lessen or significantly impede competition (section 7 of the Clayton Act 1914 and the EU Merger Regulation, Council Regulation 139/2004). ${ }^{5}$

In many countries, the purpose of antitrust legislation, and its core concepts, is not precisely defined. ${ }^{6}$ For example, legislation in the EU and the US does not make its purpose explicit or provide definitions of its central substantive terms, such as, respectively, "restraint of trade", "monopolization", "substantial lessening of competition" and "restriction" of competition, "abuse", "dominant position" and "significant impediment to effective competition". Rather, the task of putting flesh on these laws' skeletal provisions has been left to be developed in the jurisprudence and to be decided, ultimately, by the Supreme Court (in the US) and the Court of Justice of the European Union (in the EU, comprised of the Court of Justice (CJ) and the General Court (GC)). ${ }^{7}$ Over the years, therefore, these courts have had to wrestle with the plethora of complex questions and issues that application of the laws has raised. These include what their goals are and how the overarching objectives guide interpretation of their key words and the crafting of tests to anticompetitive or restrictive conduct and to distinguish

1 William E. Kovacic \& Marianela Lopez-Galdos, Lifecycles of Competition Systems: Explaining Variation in the Implementation of New Regimes, 79 Law \& Contemp. Probs. 101, 101-02 (2016). In contrast, "Until the mid 20th century less than 10 competition regimes existed worldwide" (UNCTAD) http://unctad.org/en/Pages/DITC/CompetitionLaw/ResearchPartnership/Benchmarking-Competition.aspx.

2 Section One provides that "[e]very contract, combination ... or conspiracy, in restraint of trade or commerce among the several States, or with foreign nations, is declared to be illegal." 15 U.S.C. $\S 1$.

3 Art 101(1) prohibits agreements between undertakings which affect trade between Member States and have as their object or effect the prevention, restriction or distortion of competition. Art 101(3) provides a legal exception from the Art 101(1) prohibition for agreements which satisfy its four conditions, see eg, Alison Jones and Brenda Sufrin, EU COMPETITION LAW: TeXT, CASES, AND MATERIALS (OUP, $6^{\text {th }}$ edn, 2016), Chaps 3 and 4.

4 Section Two, 15 U.S.C. $§ 2$, prohibits any person from monopolizing or attempting to monopolize trade, whilst Article 102 prohibits abuse of a dominant position held by one or more undertakings.

5 Clayton Act, section 7, 15 U.S.C. § 18, prohibits merger transactions which will substantially lessen competition whilst the EU Merger Regulation, [2004] OJ L 24/1, provides for concentrations which would significantly impede effective competition in the EU, or a substantial part of it, to be declared incompatible with the common market.

6 On the modern debate about antitrust's goals, see Symposium, The Goals of Antitrust, 81 Ford. L. Rev. 2151 (2013).

7 Treaty on European Union, Art 19. 
it from procompetitive or competitively neutral conduct (or, to paraphrase Justice Stephen Breyer, to separate the antitrust goats from the beneficial sheep) ${ }^{8}$

Commentary in both jurisdictions has repeatedly debated whether, and when, it is more efficient to use "rules" or "standards" to determine the legality of conduct subject to the antitrust laws and how such rules or standards should be formulated. ${ }^{9}$ An extensive literature has identified the tensions between the desire for the competition law to be accurate and consistent, yet also clear, predictable, transparent, administrable and not too costly to apply; the question of when complex standards may be more appropriate than simpler, bright line rules (or vice versa) is well rehearsed. ${ }^{10}$

The difference between rules and standards is a matter of degree and the line between them can be fine. Some rules begin to resemble standards when, for the sake of accuracy, they require consideration of additional circumstances. By the same measure, a standard may incorporate decision-making principles that seek to attain some of the clarity associated with rules. ${ }^{11}$ The blurring of the lines between rules and standards has led to debate, in the antitrust context, as to whether doctrine governing firm behaviour should present a sharp dichotomy with two wholly distinct realms - one compartment in which some conduct is prohibited (or approved) categorically, and a separate compartment in which conduct is subject to a more elaborate examination of purpose and actual or likely effects - or whether there should be a

8 Leegin Creative Leather Prods., Inc. v. PSKS, Inc., 551 U.S. 877, 914 (2007) (Breyer, J., dissenting).

9 We use the terms "standard" and "rule" in the manner set out in Ehrlich's and Posner's formative paper on the design of legal rules, Issac Ehrlich \& Richard A. Posner, An Economic Analysis of Legal Rulemaking, 3 J. Legal Stud. 257 (1974). The term "standard" refers to "a general criterion of social choice," such as a mandate to promote "competition." The term "rule" refers to a more precise statement that circumscribes the assessment of factors relevant to a decision according to the standard. Id. at 258 . The relative efficacy of rules and standards is an issue of virtually universal concern in the field of law. See, e.g., Sepehr Shahshahani, The Nirvana Fallacy in Fair Use Reform, 18 Minn. J. L., Sci. \& Tech 273., 283 \& n. 59 (2015) (collecting sources); Daniel A. Crane, Rules Versus Standards in Antitrust Adjudication, 64 Wash. \& Lee L. Rev. 49, $52-54$ \& n. 11 (2007) (hereinafter Rules Versus Standards) (collecting sources); Louis Kaplow, $A$ Model of Optimal Complexity of Legal Rules, 11 J. L. Econ \& Org. 150 (1995).

10 See further Section 2 below. Informative treatments of this topic in antitrust law include Crane, Rules Versus Standards, note 9; Wolfgang Kerber, 'Rules vs Standards' or Standards as Delegation of Authority for Making (Optimally Differentiated) Rules, in INTERNATIONALIZATION OF THE LAW AND ECONOMIC ANALYSIS 489 (Thomas Eger et al. eds., Springer, 2008); Andrew I. Gavil, Moving Beyond Caricature and Characterization: The Modern Rule of Reason in Practice, 85 So. Cal. L. Rev. 733 (2012); Yannis Katsuulakos \& D. Ulph, On optimal legal standards for competition policy: A general welfare-based analysis, 57 J. Indus. Econ. 410 (2009): Symposium: The Future Course of the Rule of Reason, 68 Antitrust L.J. 331 (2000); Leon B. Greenfield \& Daniel J. Mathieson, Rules Versus Standards and the Antitrust Jurisprudence of Justice Breyer, Antitrust, Summer 2009, at 87 (reviewing rules versus standards debate in context of analyzing opinions of a jurist who has focused on tradeoffs between the two approaches to formulating legal commands). For a discussion of the issue as it arises in the treatment of vertical restraints, see OECD Policy Roundtables: Resale Price Maintenance (2008), available at http://www.oecd.org/daf/competition/43835526.pdf and Matthew Bennett et al., Resale Price Maintenance: Explaining the Controversy, and Small Steps Towards a More Nuanced Policy (2011) 33 Fordham International Law Journal 1278, 1281-1282 (conducting a detailed assessment in every case might impose too high a burden on firms, competition agencies (and other claimants) and courts). A separate literature discusses analytical approaches that enforcement agencies can sequence the collection and assessment of information needed to apply a legal regime that subjects some conduct to assessment by bright-line rules and reviews other behavior with standards., See Damien J. Neven, Identifying "Restrictions of Competition" Some Comments from a Law and Economics Perspective, in The Notion of Restriction of Competition 39 (Damien Gerard et al. eds., 2017)

11 See Carol M. Rose, Crystals and Mud in Property Law, 40 Stan. L. Rev. 577 (1988). 
continuum of tests - a mix of rules, standards, and hybrid approaches in between. In particular, whether and when there should be:

- categorical rules that condemn certain conduct (for example, the US rule of per se illegality);

- categorical rules that allow certain conduct (rules of per se legality);

- standards that test conduct with a more complex, multi-faceted analysis of the restrictive and procompetitive effects of each agreement, accounting for the context in which the behaviour took place and the situation that would occur without the agreement; and/or

- intermediate types of analysis developed, such as a rule which requires the weighing or balancing of certain factors before it is applied, the application of rebuttable presumptions of legality or illegality, or a structured standard which requires a series of specified factors to be taken into account.

Where courts, as they have in the US, conclude that antitrust chiefly seeks to promote economic efficiency (allocative, productive, and dynamic), economics will guide the answer to these questions. Here a central focus of analysis is to assess how likely it is that the conduct at issue will permit the relevant firm(s) to exercise market power ${ }^{12}$ and interfere with the competitive process, and deny consumers the products and/or services which offer the best value for money.

A legal system cannot always completely reflect the principles underpinning it. In practice, there rarely is a perfect fit between a chosen legal rule and the conduct to be controlled. Antitrust rules almost inevitably suffer, in varying degrees, from one of two flaws. Some are overinclusive in the sense that they condemn conduct that sometimes is competitively benign or beneficial - referred to by economists as Type I error. Other rules are underinclusive in the sense that they sometimes tolerate conduct that in fact is competitively destructive - referred to by economists as Type II error. The presence of Type I or Type II errors creates incentives that affect the behaviour of firms, courts, and competition agency decision makers. ${ }^{13}$ For example, an overinclusive rule of illegality may not only deter firms from engaging in procompetitive arrangements but may also result in harmful distortions in the law if decisiontakers do not fully support the rule and seek ways to avoid its application. ${ }^{14}$ In deciding on the correct approach, an antitrust regime must therefore consider how to minimise risks of Type I and Type II errors.

In this paper we concentrate principally on the question of how this debate affects the analytical framework for identifying infringing agreements in the US and EU. Although the principles discussed in this paper are relevant to all three substantive pillars of antitrust, voluminous debates in recent commentary have focused on how to construct a test, or tests, to identify unlawful abusive or exclusionary behaviour and to distinguish it from competition on the merits; and what tools or methods can be used to identify mergers which are liable to

12 Market power is the ability to maintain prices above competitive levels for a significant period of time or to maintain output in terms of product quantities, product quality and variety or innovation below competitive levels for a significant period of time and/or achieve offsetting efficiencies, Andrew I. Gavil et al., Antitrust LaW in Perspective: Cases, Concepts and Problems in Competition Policy (Thomsen West, 3d ed., 2017), at 18, 28-30.

13 On the assessment of error costs in formulating and applying liability rules antitrust cases, see Jonathan B. Baker, Taking the Error Out of Error Costs: What's Wrong with Antitrust's Right, 80 Antitrust L.J. 1 (2015).

14 See e.g., notes 94-100 and text. 
harm consumer welfare. In our view, despite useful recent scholarship that proposes analytical improvements, the question of how agreements are to be analysed under both the US and the EU jurisprudence is also unduly opaque; it is frequently difficult to ascertain whether agreements, including joint venture and other horizontal collaboration and distribution agreements, are compatible with the law. In particular, confusion about the role and scope of per se rules, the role and scope of ancillary restraint doctrines, and how competing anti- and procompetitive effects of mixed agreements are to be balanced against each other have led to excessive complexity in the system. Given the necessity for firms to be able to assess the antitrust risk involved in concluding their day-to-day commercial agreements this remains a matter of acute importance.

This paper commences in section 2 by considering what factors might shape development of a coherent and optimal framework for antitrust analysis in a jurisdiction. Once these factors have been set out, sections 3 and 4 examine respectively how US and EU competition law have approached the issues identified in relation to the analysis of agreements and what features of each system have moulded the developments there. Section 5 concludes that both systems require some development to create more intelligible frameworks for antitrust analysis of agreements based on common concepts rather than historical categories of antitrust analysis. Competition agencies could play an important part as catalysts in this progress. Indeed, one problem in particular, has been that because in more recent years European Commission (Commission) enforcement under Article 101 has focused most closely on cartels a majority of cases arising before the EU Courts relate to issues arising in cartel cases many of which do not involve matters involving the substantive tests used to identify infringements. The paucity of cases on this latter issue imparts a staccato quality to the development of doctrine, as it denies courts the opportunity to refine analytical principles incrementally. Greater enforcement of complex cases by the Commission seems necessary to ensure that cases are brought before the courts which enable the desired evolution to occur.

Before proceeding, we address one point of terminology. The Commission describes the enforcement of Articles 101 and 102 as "antitrust" and distinguishes it from merger enforcement. In the United States, the term "antitrust" encompasses both merger and nonmerger enforcement. In this Article we speak of antitrust in the broader US manner as encompassing all areas of competition law, including the prohibition of certain forms of agreements.

\section{DeVeloping A COHERENT FRAMEWORK: THE DESIGN OF LEGAL COMMANDS}

As noted above, Section One and Article 101 articulate general commands which require further specification to be implemented in practice. In this section, we examine the considerations that the EU and US antitrust regimes, as well as other competition law systems, must account for in determining how to apply these broad mandates.

\section{A. Identifying Objectives}

The development of implementing tests first must examine the law's objectives. Systems vary in how lawmakers communicate these aims. Sometimes the statute's text sets out the goals. In other regimes, the law's aims appear in legislative history, including reports of legislative committees or floor debates that precede enactment. The complexity of the implementing rules depends heavily on the nature of the goals to be achieved. A "purist" efficiency-oriented antitrust regime provides a relatively simpler (though hardly simple) task for rule formulation than a system that seeks to attain multi-faceted goals. Ideally, a legislature that establishes a multi-goal regime will identify a hierarchy of aims, assign weights to each goal, and indicate how to resolve conflicts among them. Whatever goal structure is chosen, the competition system's analytical concepts should be common for all 
three pillars of antitrust - agreements/ dominant firm conduct/ mergers (dealing with types of conduct which may have negative effects on competition). ${ }^{15}$

\section{B. Rules and Standards: General Considerations}

A sound competition law system seeks to avoid both overreliance on bright line rules (or the misuse of categorical analysis) and the indiscriminate acceptance of open-ended, multifactored standards to analyse conduct. ${ }^{16}$ As described more fully below, either tendency presents hazards. Excessive reliance on bright-line rules (to condemn or to exculpate) can sacrifice economic benefits generated by practices which pose some competitive dangers but, in important circumstances, serve valuable ends, or render decision-takers powerless to act against conduct which has the ability to harm competition. An obsession with applying bright-line rules also can tempt enforcement agencies and courts to manipulate the rules - by extending or narrowing them rather than focussing needed attention on actual or likely competitive effects. ${ }^{17}$ At the same time, bright-line rules can serve important ends (particularly, the attainment of procedural economy) when the rules rest upon a sound understanding, from theory and experience, that the practice in question typically imposes harm (a rule to condemn) or normally has benign or procompetitive effects (a rule to exculpate).

Just as competition law at times has leaned too heavily on bright-line rules, on other occasions it too willingly has resorted to open-ended standards to solve recurring analytical problems. To some degree, this tendency is understandable. At first glance, a mandate to forbid behaviour that endangers competition might seem to demand a broad inquiry into a wide range of considerations that bear upon the conduct's effects. A number of landmark US decisions are famous for their recital of myriad factors that should be examined to determine the legality of challenged practices. ${ }^{18}$ To posit the apparent inevitability of substantial analytical complexity incorrectly suggests that all antitrust inquiries must be time-consuming, resource-intensive endeavours, and it obscures possibilities for analytical short-cuts that can reach the correct result at lower cost to the parties and courts. The sense that broad reasonableness standards invariably, or usually, serve to exonerate defendants can induce an exaggerated shift to the use of bright-line rules of prohibition. ${ }^{19}$

If, as is common in most competition law systems, the legal regime employs a mix of brightline rules and standards, the regime will require an initial sorting exercise that places

15 See Gavil et al., note 12, at v. ix-x; Gavil, note 10, at 735; Carles Esteva Mosso, The Contribution of Merger Control to the Definition of Harm to Competition in THE NOTION OF RESTRICTION OF COMPETITION 311 (Damien Gerard et al., eds., 2017), (GCLC Conference, Brussels, Feb. 1, 2016) available at http://www.ec.europa.eu/competition/speeches/text/sp2016_03_en.pdf.

16 Novell, Inc. v. Microsoft Corp., 731 F.3d 1064, 1073 (10 ${ }^{\text {th }}$ Cir. 2013 (Gorsuch, J.) (“[O]f course, most every rule proves over- or under-inclusive in some way."); MindGames, Inc. v. Western Pub. Co. Inc., 218 F.3d 652, at 657 ( $7^{\text {th }}$ Cir. 2000) (Posner, J.) ("No sensible person supposes that rules are always superior to standards or vice versa").

17 Mark A. Lemley \& Christopher B. Leslie, Categorical Analysis in Antitrust Jurisprudence, 93 Iowa L. Rev. 1207 (2008).

18 Brown Shoe Co. v. United States, 370 U.S. 294 (1962); Board of Trade of the City of Chicago v. United States, 246 U.S. 231 (1918).

19 This arguably took place in the United States from the early 1940s through the early 1970s, when the Supreme Court expanded the range of conduct subject to per se condemnation. See William E. Kovacic \& Carl Shapiro, Antitrust Policy: A Century of Economic and Legal Thinking, 14 J. Econ. Perspectives 43, 4950 (2000) (describing increased reliance on per se rules to condemn business conduct). 
observed behaviour into one of two baskets: conduct suitable for summary condemnation (or approval), and conduct requiring a more elaborate inquiry. This first step - referred to below as "characterization" or "classification" - involves a preliminary assessment of the competitive consequences of the behaviour. Antitrust-relevant conduct ordinarily does not appear before the enforcement agency or the court with a convenient, easily recognized label that unambiguously identifies its character. ${ }^{20}$ The application of a system that employs a mix of rules and standards requires a threshold decision, explicit or implicit, that the behaviour belongs in one category or the other. It is impossible to make this threshold choice without some assessment (perhaps very abbreviated) of whether the conduct has redeeming merit.

\section{A Role for Rules of Illegality?}

In a pivotal early judgment in US antitrust law, the Supreme Court in Standard Oil Co. of New Jersey v. United States ${ }^{21}$ established the rule of reason as the baseline analytical method to applying the Sherman Act's ban on contracts in "restraint of trade". 22 In so doing it left open the possibility that certain behaviours might be so inherently dangerous that they could be banned in a summary manner - in what US antitrust law would come to call a per se rule of illegality. ${ }^{23}$ Later decisions realized this possibility by denominating various practices for which illegality is established simply by proof that two or more parties formed agreements to engage in the behaviour. ${ }^{24}$

Commentators generally agree that summary condemnation is appropriate for conduct manifestly anticompetitive and most unlikely to have offsetting benefits. A rule of categorical illegality provides the benefit of clarity and procedural economy which is calculated to outweigh the cost of some false positives. Many jurisdictions apply a rule of per se illegality, or virtual per se illegality, against some horizontal arrangements, such as price fixing. The extent to which such a rule should be expanded beyond this, for example to vertical practices, single-firm exclusionary behaviour or to new types of conduct arising, is much more controversial and contested.

This category must, however, be confined narrowly and appropriately otherwise it will fall into disrepute and decision-takers may seek ways of avoiding its consequences. Means of evasion include prioritisation by which a competition agency decides not to bring cases, or by manipulating law in other ways to avoid finding an infringement (such as making it more difficult for a claimant to bring an action or prove the existence of an agreement ${ }^{25}$ or

20 On rare occasions, prosecutors will collect evidence that shows the unmistakable awareness of the business officials that they are engaged in an illegal collusive scheme. See United States v. Andreas, 216 F.2d 645 ( $7^{\text {th }}$ Cir. 2000) (recounting evidence that Justice Department used to prosecute lysine cartel participants).

21221 U.S. 1 (1911).

22 Id. at 60 ("[T] whether in a given case a particular act had or had not brought about the wrong against which [Section One of the Sherman Act] provided.").

23 See id. at 65 (observing that previous Supreme Court decisions established that the "nature and character" of certain contracts create "a conclusive presumption" that such contracts violate the Sherman Act).

24 See, e.g., United States v. Socony-Vacuum Oil Co., 310 U.S. 150 (1940) (prohibiting all agreements to fix or stabilize prices); Timken Roller Bearing Co. v. United States, 341 U.S. 593 (1951) (forbidding all agreements to allocate customers or geographic markets); United States v. Arnold, Schwinn \& Co., 388 U.S. 365 (1967) (forbidding all agreements by which a manufacturer limited its retailers to specific geographic territories).

25 For example, the US Courts have: raised requirements that plaintiffs must satisfy to plead the fact of concerted action (see discussion of Matsushita Electric Industrial Co v. Zenith Radio Corp 475 US 574 
modifying or providing exceptions to the rule ${ }^{26}$ ) which might have broader implications and make other antitrust actions harder to bring.

Another, more principled approach to limitation is to expressly recognize exceptions to a general rule of prohibition through a characterization process. As examined more completely in Section 3, from the early days of the Sherman Act courts sought to avoid false positives associated with summary condemnation of severe horizontal restraints such as price restrictions by recognizing the ancillary restraints doctrine, which excused restrictions deemed necessary to the success of an efficiency-enhancing collaboration of competitors. ${ }^{27}$ The process of making exceptions - defining conduct that qualifies for more lenient treatment while preserving a zone of practices always forbidden - places a premium on clarity in specifying how, in the typical case, a court is to determine whether a practice deserves more elaborate examination. At the same time, there may be behaviour which strongly resembles conduct subject to categorical prohibition yet also presents possible efficiency justifications. In these conditions, the perceived inadequacy of a binary decision making calculus (the conduct is always bad, therefore condemn versus the conduct has ambiguous effects, therefore undertake an exhaustive, fact-intensive inquiry) led courts to recognize tests that employ rebuttable presumptions of illegality - known in the US as a truncated rule of reason analysis or a quick look - to assess efficiency claims. ${ }^{28}$

\section{A Role for Rules of Legality?}

As an antitrust system denominates certain behaviour as so dangerous to warrant categorical disapproval, it also might preclude challenges to conduct that always, or ordinarily, is believed to have benign or procompetitive effects. ${ }^{29}$ The logic of per se rules to exculpate is essentially the same as the logic of per se rules to condemn. Such rules provide valuable clarity to business officials by identifying "safe harbours" in which they can operate without attack, and they avoid the expenditure of resources to assess the impact of practices that usually improve competition or, at a minimum, do not endanger it. As with a rule of categorical prohibition, a rule of per se legality creates error risks, in this case of

(1986) and Bell Atlantic Corp v. Twombly 550 US 554, 557 (2007) notes 99-100 and text); and demanded greater proof to establish the requisite form of illegal agreement in a minimum resale price maintenance ("RPM") case (see discussion of Business Electronics Corp. v. Sharp Electronics Corp 485 US 717 (1988) note 94 and text).

26 A major step in the Supreme Court's erosion of the per se ban against RPM established in Dr. Miles was to withdraw maximum RPM from the rule's coverage (see State Oil v. Khan 522 US 3 (1997) note 98 and text). Since the 1930s and 1940s, the Supreme Court has labeled tying arrangements as per se offenses, even though a plaintiff must demonstrate that the defendant has market power in the tying product (a factor which is irrelevant in the traditional formulation of the per se offence, see Socony-Vacuum note 24), see Jefferson Parish Hosp. Dist. No. 2 v. Hyde, 466 U.S. 2 (1984).

27 United States v. Addyston Pipe \& Steel, 85 F. 271 (6th Cir. 1898), aff'd, 175 U.S. 211 (1899).

28 NCAA v. Bd. of Regents of Univ. of Okla., 468 U.S. 85 (1984); Polygram Holding, Inc. v. Federal Trade Comm'n, 416 F.3d 29 (D.C. Cir. 2005).

29 Compare Texaco Inc. v. Dagher, 547 U.S. 1, 7 (2006) (per se prohibition of internal pricing decisions of a legitimate joint venture "would be inconsistent with this Court's precedents"); James Keyte, "Quick Looks" and the Modern Analytical Framework for Assessing Legitimate Competitor Collaborations, Antitrust, Summer 2016, at 23, 25-29 (interpreting Dagher and American Needle, Inc. v. National Football League, 560 U.S. 183 (2010) as approving use of quick look analysis to uphold core collaboration activities of efficiency-enhancing joint ventures and restraints imposed within the scope of the collaboration). 
underinclusiveness; it ignores instances in which the conduct presumed to be acceptable causes actual competitive harm.

Professor Daniel Crane has offered a separate rationale for using bright-line rules as immunizing devices for broad swaths of industrial behaviour while preserving a role for standards in determining liability for conduct falling outside of safe harbours. ${ }^{30}$ Clear rules provide optimal incentives to engage in beneficial competitive behaviour and reduce litigation costs - and to deter unmeritorious antitrust actions/rent seeking behaviour that are likely to be threatening when the governing law is presented as standard. In this context underinclusive rules are optimal when intervention is believed to pose a high risk of chilling efficient conduct. Certain forms of single-firm conduct often are offered as candidates for complete immunity on this basis.

To this point, we have focused on the courts as the mechanisms for determining when rules or standards are appropriate methods of analysis. Legislatures and enforcement agencies can perform the same function. Singapore's competition law, for example, excludes vertical agreements from the provision dealing with concerted practices. ${ }^{31}$ Such measures, in effect, reserve supervision of vertical agreements to the examination of dominant firms and accept possible false negatives that arise if non-dominant enterprises employ vertical contractual restraints which harm competition. Another approach is for the enforcement agency to issue enforcement guidelines or regulations that recognize safe harbours - for example, to exempt parties with low market shares which incorporate less offensive restraints within their agreements. ${ }^{32}$ These forms of agency policy making ordinarily do not provide an absolute rule of legality; the competition agency prospectively can alter its policy and modify or withdraw the protection, and the competition agency's guidelines might not preclude other enforcement mechanisms (e.g., private rights of action, lawsuits by other public enforcement agencies not subject to the competition agency's control) from challenging conduct that the guidelines would leave untouched.

\section{E. Devising Workable Standards}

Perhaps the greatest challenge of modern policy regarding agreements is what Phillip Areeda called "administrability". ${ }^{33}$ For some time there was concern in the US that the rule of reason standard articulated in cases such as Board of Trade of the City of Chicago v. United States, ${ }^{34}$ involved an expensive, indeterminate examination of challenged conduct which, in practice, tended to exonerate defendants. ${ }^{35}$ The perception of the rule of reason as unmanageable and,

30 Crane, Rules Versus Standards, note 9, at 99-100.

31 Competition Act, Third Schedule para. 8. See also discussion of EU block exemption regulations in Section 4. Many jurisdictions have enacted statutes that exempt entire sectors or types of transactions from the application of the antitrust laws. For example, protections for collective bargaining agreements are commonplace. Daniel J. Gifford, Redefining the Antitrust Labor Exemption, 72 Minn. L. Rev. 1379 (1988) (discussing the US labor exemption).

32 See e.g., discussion of block exemptions and de minimis principle in Section 4. In analyzing vertical issues, the US courts have tended to dismiss claims where market shares are relatively low, see note 110 and text.

33 Phillip Areeda, Monopolization, Mergers, and Markets: A Century Past and the Future, 75 Cal. L. Rev. 959, 965-70 (1987) (discussing importance of administrability as factor in setting antitrust tests for predatory pricing).

34246 U.S. 231 (1918).

35 Commentary that has interpreted Chicago Board of Trade in this manner is collected in Gavil, note 10, 733, $733 \&$ n.3. Defendants in antitrust cases typically press for a broad interpretation of the rule of reason's 
as applied, permissive can introduce unfortunate distortions into a competition law system. Such was the case in US jurisprudence from the early 1940s through the early 1970s, when the Supreme Court, fearing that courts were 'of limited utility in examining difficult economic problems' and weighing competing economic effects ${ }^{36}$ dramatically expanded the category of agreements deemed to be illegal per se., in many cases with considerable cost to efficiency.

Awareness of the problems associated with seemingly formless standards has inspired an extensive modern search for methods to make the traditional rule of reason more workable. Commentators and enforcement agencies have made extensive efforts to suggest how a reasonableness standard might be structured to minimize the information costs associated with the traditional formula and to sort out, at a more preliminary state of the analysis, whether the challenged conduct presents serious competitive hazards and whether efficiency considerations might justify the behaviour. These structured or truncated forms of analysis often rely on presumptions to determine which party bears the burden of coming forward with evidence, respectively, about competitive harms and justifications.

The pursuit of more manageable standards has yielded two noteworthy developments in the US. First, the courts have recognized the availability of analytical techniques that stand between the poles of absolute prohibition and a "full blown" reasonableness inquiry. ${ }^{37}$ As a related matter, courts have employed a burden-shifting framework to organize the evaluation of theories of harm and supporting evidence in agreements, mergers, and monopolization cases. ${ }^{38}$ The result has been a detectable movement away from analysis based on the classification of conduct into specific categories, and a movement toward a more conceptbased approach, which focuses on three essential concerns: the theory of harm, proof of actual or likely adverse effects and assessment of countervailing efficiencies. Despite progress on these fronts, difficult conceptual issues remain unresolved. Most notably, there remains considerable debate over the test to be applied to restraints deemed to be helpful to the realization of efficiencies or other worthy aims. Must the defendants show that such restraints are "indispensable" or "necessary" to the attainment of valid ends, or is it sufficient that they be "reasonably necessary" for the purpose asserted? Can the plaintiff prevail by demonstrating that the defendant could have availed itself of less restrictive measures to achieve the claimed efficiencies and/or how can competing harms and benefits be weighed?

Secondly, the work of courts has been supplemented and, in some instances, influenced by the issuance of enforcement agency guidelines, notices, and speeches. Collectively, the use of these tools has sought to clarify the policy goals to be achieved, to specify the factors to be considered and the weight to be assigned to each, and to suggest the ordering of the analysis,

demands to improved their prospects of success in litigation. See 7 Phillip E. Areeda \& Herbert Hovenkamp, ANTITRUST LAW 1 1511a, at 464 (3d ed. 2010) ("The defendant invokes the rule of reason in order to maximize the plaintiff's burden and its own chances of prevailing on the merits or of outlasting plaintiffs lacking the energy, time, or money for a lengthy inquiry into reasonableness.").

Topco Assocs., Inc. v United States, 405 U.S. 596, 609-610 (1972), see note 77.

37 See, e.g., Polygram, note 28.

38 United States v. VISA USA, Inc., 344 F3d 229, 238 (2d Cir. 2003) (agreements); United States v. Microsoft Corp., 253 F.2d 34 (D.C. Cir. 2001) (per curiam) (monopolization); United States v. Baker Hughes Inc., 908 F.2d 981 (D.C. Cir. 1990) (merger). See also Gavil, note 10, at 737 (describing this trend). In a rule of reason case, the plaintiff bears the burden of proving that the net effect of the conduct at issue is to reduce competition. See Andrew I. Gavil, Burden of Proof in Antitrust Law, in 1 American Bar Association Antitrust Section, Issues in Competition Law and Policy 125 (2008). 
The influence has been most pronounced in the field of merger control in the US, where judicial decisions frequently employ the methodology set out Burin agency guidelines. ${ }^{39}$ Other US guidelines specifically designed to shape the treatment of conduct involving concerted action have had less success in shaping doctrine. ${ }^{40}$ In the EU, in contrast, guidelines have been more influential with businesses frequently looking to them for direction.

Although guidelines and other supplemental tools are valuable elements of the EU and US competition law systems, the litigation of cases and the issuance of judicial decisions continue to supply the most important source of policy development. As noted below, a basic, sustaining level of litigation is necessary to give courts opportunities to upgrade doctrine as understanding about the competitive significance of individual practices evolves, and the state of the analytical art, as advanced in commentary and enforcement agency practice, improves.

\section{F. The Impact of the Enforcement Structure}

The mechanism chosen for enforcement can exert a major influence over the competition system's reliance on rules or standards. One important determinant is the presence or absence of criminal sanctions for infringements. ${ }^{41}$ A jurisdiction with criminal sanctions may feel a stronger need, than a system enforced solely through civil punishments, to delineate clear categories of forbidden behaviour. In this context, rules of per se illegality serve to provide plain warning to business officials of when the state will impose criminal sanctions. This clarity can be essential to establish, in the eyes of jurors and courts (in sentencing decisions), that serious sanctions are warranted. A criminal enforcement regime that relied on standards might well be seen as illegitimate, and jurors might readily be persuaded not to convict individuals who are claimed to have transgressed an arguably hazy legal command. For this reason, and to facilitate effective criminal enforcement, the US Department of Justice has insisted on preserving the recognition of certain horizontal restraints as illegal per se and not subject to qualification.

An antitrust system that prescribes civil monetary sanctions can face the same challenge. As civil penalties become more severe (e.g., mandatory treble damages in private US antitrust suits and huge fines in EU administrative procedures), there may a perceived need to clarify the circumstances - e.g., by setting bright line rules to condemn or to exculpate - in which infringements will trigger such sanctions. If civil sanctions are powerful, and courts believe them to be excessive in important categories of cases, judges may use a variety of

39 See United States v. H \& R Block, Inc., 833 F. Supp. 2d 36 (D.D.C. 2011). On the elements of effective agency guidance, see Hillary |Greene, Guideline Institutionalization: The Role of Merger Guidelines in Antitrust Discourse, 48 Wm \& Mary L. Rev. 771 (2006); William Blumenthal, Clear Agency Guidelines: Lessons from 1982, 68 Antitrust L.J. 5 (2000)

40 U.S. Dep't of Justice \& Federal Trade Commission, Antitrust Guidelines for Collaborations Among Competitors (2000), available at https://www.ftc.gov/sites/default/files/documents/public_events/jointventure-hearings-antitrust-guidelines-collaboration-among-competitors/ftcdojguidelines-2.pdf. On the US competitor collaboration guidelines, see Robert A. Skitol, Yes, the Competitor Collaboration Guidelines Are Ripe for Revision, Antitrust, Summer 2016, at 42; W. Stephen Smith et al., Revising the Competitor Collaboration Guidelines: Three Easy Pieces, Antitrust, Summer 2016, at 47.

${ }^{41}$ See generally Criminalising CARTELS (Caron Beaton-Wells \& Ariel Ezrachi eds., Hart Publishing, 2011). 
"equilibration" techniques, including some of those already discussed, to make it more difficult for plaintiffs to avail themselves of per se rules of condemnation. ${ }^{42}$

Another factor concerns the assignment of decision-making tasks in the resolution of antitrust disputes. The US antitrust system permits plaintiffs to demand jury trials in civil cases, and the norm among systems that impose criminal punishment is to try criminal cases before juries. The use of juries can press in the direction of employing bright lines to inform the deliberations of jurors. This reflects, in effect, concerns about the capacity of non-specialist jurors to sort through complex evidence relevant to a finding of guilt or innocence. Further, in the EU, for example, the initial decision to confer the right to decide whether an individual agreement satisfied the conditions of Article 101(3) on a sole integrated decision-taker, the Commission, appears to have had a significant impact on substantive doctrine. The Commission's exclusive right over Article 101(3) seems to have inspired, or at least encouraged, its early formalistic interpretation to the concept of a restriction of competition under Article 101(1), which brought many agreements within it and consequently cemented the Commission's central role in the development of EU competition policy. ${ }^{43}$ The subsequent transition to a decentralised enforcement system in the EU - relying on the national enforcement agencies and national courts as well as the Commission - may also be encouraging support for clearer rules which facilitate uniform and consistent interpretation of the law throughout the EU.

Concerns about the capacity of the institutions entrusted with implementation have also emerged in debates about the choice of rules or standards in older competition law systems and in newer regimes established in transition economies. The Supreme Court's frequent endorsement of per se rules to condemn from the 1940s into the early 1970s rested in part on a stated concern that courts were ill-equipped to assess economic arguments and evidence that would be submitted as part of a more elaborate examination of certain business practices. ${ }^{44}$ The attractiveness of bright-line rules might be still stronger in in settings where the initial conditions favourable to enforcement in older market systems (e.g., broad business awareness of competition law, high quality courts, and skilled enforcement agencies) are lacking. In such settings, a case might be made for the adoption of simpler rules to educate businesses about their duties, to inform the enforcement decisions of competition agencies, and to guide the courts in evaluating challenged conduct.

\section{ANALySis IN THE UNITEd STATES}

The United States has the most extensive experience in addressing the issues introduced in Section 2. As described above, the general progression in US doctrine has been toward recognition of an analytical continuum whose boundaries are set, respectively, by a rule of categorical condemnation (per se illegality) and an elaborate, fact-intensive assessment of reasonableness. ${ }^{45}$ These poles are connected by a range of intermediate tests that seek to

42 Steven Calkins, Summary Judgment, Motions to Dismiss, and Other Examples of Equilibrating Tendencies in the Antitrust System, 74 Geo. L.J. 1065 (1986).

43 See note 121 and text; see also Sir Christopher Bellamy, "Restriction of Competition" - A Historical Approach, in The Notion of Restriction of Competition 31, 35-36 (Damien Gerard et al. eds., 2017) (discussing tendency of European Commission prior to 2004 to interpret "restriction of competition" under Article 101 broadly).

44 See discussion of United States v. Topco Assocs. Inc., 405 U.S. 569, 609-10 \& n.10 (1972) note 75 and text.

45 See Crane, Rules Versus Standards note 9, at 50 ("Antitrust finds itself in the midst of a creeping transition from rules to standards."). 
combine some of the clarity and economy of bright-line rules with the greater analytical accuracy that a fuller examination of evidence can produce.

\section{A. Goals}

Since the late 1970s, the US courts have accepted view that antitrust law is a "consumer welfare prescription." ${ }^{46}$ This indicates that US law is concerned with claims by individual firms only to the extent that their injury corresponds to harm to consumer interests. The disappearance of firms that does not impose such harm is irrelevant to modern US antitrust analysis. The focus on consumer welfare generally distinguishes US law from what economists refer to as a "total welfare" test, which is indifferent to redistributions of wealth from consumers to producers, so long as challenged business practices have positive efficiency effects. ${ }^{47}$ As applied by US enforcement agencies and courts, the consumer welfare standard generally recognizes efficiency claims only if the asserted efficiencies are passed along to consumers.

The modern consumer welfare, efficiency orientation of US doctrine departs significantly from earlier jurisprudence which said antitrust law willingly should sacrifice efficiency considerations in order to protect smaller firms and preserve a more egalitarian business environment. As Professors Roger Blair and Daniel Sokol observe, the modern US approach to goals reflects the view that the pursuit of other policy goals is best left to other fields of public policy. The US antitrust system is:

'technocratic in the sense that antitrust be defined narrowly to examine only those issues that are purely without antitrust's ability to be measured and understood using industrial organization as the basis for economic analysis. This technocratic approach moves non-competition economic considerations to areas such as sector regulation, the legislative process, or executive fiat. Such areas are better equipped than antitrust to deal with political trade-offs between law and policy. ${ }^{48}$

In recognizing this consensus, we do not assert that it is immutable. In recent years, many commentators have argued that the consumer welfare orientation deflects needed attention away from other valid policy aims, including the correction of disparities in wealth within the US society. ${ }^{49}$ Appeals to populist values have appeared frequently in recent US political discourse, including specific references to the need to reorient future antitrust enforcement. Without predicting that these utterances foreshadow a reformulation of goals, at least in public enforcement, it is enough to observe that adjustments in the now 40-year-long commitment to the consumer welfare objective are hardly impossible.

46 See e.g., Reiter v Sonotone Corp 442 US 330, at 343 (1979) and NCAA, note 28, at 107-08. Statements of US enforcement officials make frequent reference to "consumer welfare" as the focus of antitrust policy. See e.g., Joel L. Klein, Assistant Attorney General, Antitrust Division, US Department of Justice, Rethinking Antitrust Policies for the New Economy 1-2 (Speech before the Haas/Berkeley New Economic Forum, Portola Valley, California, May 9, 2000).

47 See Albertina Albors-Llorens \& Alison Jones, The Images of the "Consumer" in EU Competition Law, in THE IMAgES OF THE CONSUMER IN EU LAW 43, 46-48 (Dorota Leczykewicz \& Stephan Weatherill eds., Bloomsbury, 2016) (discussing US goals framework).

48 Roger D. Blair and D. Daniel Sokol, Welfare Standards in US and EU Antitrust Enforcement (2013) 81 Fordham Law Review 2497, 2505

49 See Barak Orbach, The Goals of Antitrust, 821 Ford. L. Rev. 2151 (2013) (discussing varied aims of competition law systems). 


\section{B. Rules or Standards?}

The basic command of Section One of the Sherman Act is stated in clear-cut terms: "Every contract, combination in the form of trust or otherwise, or conspiracy, in restraint of trade . . . is declared to be illegal." 50 The seemingly absolute language of the statutory text recites none of the analytical concepts - for example, "per se illegality," "ancillary restraints," "truncated rule of reason" - that decisions since 1890 have recognized. The courts have developed these ideas through a common law decision-making process that Congress deliberately anticipated when it adopted the Sherman Act. The courts (and the FTC) were to adapt doctrine in light of new learning in economics and law about the operational content of antitrust. ${ }^{51}$

The jurisprudence of the courts since 1890, and of the FTC since 1914, has displayed recurring tensions in choosing between rules and standards to address concerted practices. These tribunals have struggled to balance the aims, described in Section 2 above, of making accurate decisions while minimizing administrative burdens and providing predictability. One interpretation of the early decades of the Sherman Act is that courts experimented with different approaches to resolve the tension between rules and standards. One formative approach emerged in the Justice Department's prosecution of Standard Oil for monopolization of the petroleum industry. The Standard Oil decision in 1911 announced that Section One of the Sherman Act established a single, general principle for the assessment of trade restraints: The "rule of reason" would govern the evaluation of business behaviour. ${ }^{52}$ As the Court later observed in Chicago Board of Trade, the "true test of legality" under this standard "is whether the restraint imposed is such as merely regulates and perhaps thereby promotes competition or whether it is such as may suppress or even destroy competition." 53

The Standard Oil judgment reflected, at least implicitly, awareness that not all cases demanded an expansive inquiry. Within the framework of what it called "the standard of reason," "54 the Standard Oil Court embraced the idea articulated in earlier cases that some restraints might be so manifestly injurious that courts could forego a more elaborate inquiry and condemn they out of hand. ${ }^{55}$ The Court noted that the "nature and character" of certain agreements might create a "conclusive presumption" that the conduct violated Section One. ${ }^{56}$ This set the foundation for what later would be seen as a dichotomy model of Section One, with conduct placed in one of two distinct baskets: summary condemnation (per se illegality)

$50 \quad 15$ U.S.C. $\S 1$.

51 State Oil, note 26, 20 (noting role of courts in US antitrust law "in recognizing and adapting to changed circumstances and the lessons of accumulated experience"); National Society of Professional Engineers v. United States, 435 U.S. 679, 688 (1978) (in adopting the Sherman Act, Congress "expected the courts to give shape to the statute's broad mandate by drawing on common-law tradition").

52 Standard Oil, note 21, at 60 ("The standard of reason . . . was intended to be the measure used for the purpose of determining whether in a given case a particular actor had or had not brought about the wrong against which [Sherman Act Section One] provided."). The Court announced that the rule of reason also governed the application of Section 2 of the Sherman Act and its prohibition against monopolization and attempts to monopolize.

53 Chicago Board of Trade, note 18, at 238.

54221 U.S. at 60.

55 Earlier cases had applied the principle that the evaluation of practices within the coverage of Section One did not invariably require extensive fact gathering or analysis. United States v. Trans-Missouri Freight Ass'n, 166 U.S. 290 (1897); Addyston Pipe note 27.

56211 U.S. at 60 (citing Trans-Missouri Freight and other cases). 
and a fuller assessment of reasonableness, which becomes known, by reason of commentary interpreting the formulation set out in Chicago Board of Trade, as a full-blown rule of reason analysis. ${ }^{57}$

A second important experiment in the Sherman Act's formative era appeared in the Judge (later President and Chief Justice) William Howard Taft's opinion for the Sixth Circuit in United States v. Addyston Pipe \& Steel Co.. ${ }^{58}$ Taft wrote against the backdrop of seemingly inconsistent Supreme Court decisions which, on the one hand, had adopted a literalist reading of Section One and concluded that "every" agreement that restrained trade violated the statute without regard to its asserted reasonableness ${ }^{59}$ and, on the other hand, appeared to call for a more context-specific analysis that accounted for efficiency-related justifications. ${ }^{60}$ Taft reconciled these approaches with a concept that came to be known as "ancillarity". ${ }^{61}$ By this concept, "naked" agreements by competitors to set prices, allocate customers, or divide markets warranted categorical prohibition without study of actual effects; harmful consequences would be presumed. ${ }^{62}$ At the same time, restrictions that served to make efficiency-enhancing arrangements (e.g., the sale of a business encompassing an increment of value for good will, or the setting of prices by partners in a law firm) deserved more elaborate analysis because they were "ancillary" to legitimate transactions. ${ }^{63}$

Taft's opinion introduced concepts that re-entered the antitrust mainstream in the 1970s with the publication of Robert Bork's Antitrust Paradox, ${ }^{64}$ which prominently featured Judge Taft's decision. Appearing at the close of the era of judicial enthusiasm for per se rules to condemn, Judge Bork's treatise helped make Addyston Pipe an important foundation for a modern jurisprudence that has retreated from expansive reliance on rules of per se illegality and has depended more heavily on various forms of more elaborate reasonableness inquiries. First, the ancillary restraints doctrine, or "ancillarity" principle, underpins the initial characterization step in Section One cases. As Taft explained, the sensibility of Section One depended on the ability of courts to distinguish between naked agreements deserving summary condemnation and restraints that required a more elaborate inquiry as they contributed to a collaboration's attainment of efficiencies ("ancillary restraints"). ${ }^{65}$ Secondly, Taft's opinion outlined a structured mechanism for conducting a more detailed inquiry, which included consideration of the proportionality of the restraint (were less restrictive alternatives available to accomplish valid objectives?). As we note below, modern decisions that have altered the balance between rules and standards have sought to devise a new framework that subsumes the ancillarity concept into a larger reformulation of Section One doctrine. Thus, ancillarity retains independent significance today, even though a modern restatement of

\footnotetext{
57 See supra note 35 and accompanying text.

58 Addyston Pipe note 27

59 Trans-Missouri note 55.

60 United States v. Joint-Traffic Ass'n, 171 U.S. 505, 567 (1898).

61 Addyston Pipe note 27, at 281-82.

62 Id.

63 Id.

64 Robert H. Bork, The Antitrust Paradox (Basic Books 1978).

65 See note 81 and text.
} 
doctrine might helpfully retire the concept as a distinct strand of analysis and instead incorporate its analytical insights into a new Section One framework.

Supreme Court decisions of the 1920s and 1930s struggled to elaborate the Section One analytical framework established in Standard Oil: an overarching rule of reason within which some types of agreements might be treated as inherently unreasonable, owing to their harmful "nature and character." In 1927, the Court appeared to give effect to the latter possibility by treating a cartel of sanitary pottery suppliers (which collectively accounted for a dominant share of sales) as illegal per se and rejecting the defendants' arguments made about the reasonableness of prices collectively established. ${ }^{66}$ Six years later, with the US in the grips of the Depression, the Court refused the request of the Justice Department to declare a joint selling arrangement of coal producers to be illegal per se and instead spoke sympathetically of the defendants' aim to respond to the harms of destructive overproduction and depressed prices. $^{67}$

In the mid- to late-1930s, national economic policy shifted away from experiments with national planning and government-business alliances that compelled rivals to cooperate in setting output levels. Competition law ascended as an economic policy tool, and the Supreme Court dramatically established the primacy of per se rules to address certain forms of agreements. In 1940 in Socony-Vacuum, the Court held that per se condemnation was appropriate for a broad range of horizontal agreements that affected prices. ${ }^{68}$ Over roughly the next three decades, the Court made clear that a rule of per se illegality applied to customer or territory allocations, ${ }^{69}$ some concerted refusals to deal, ${ }^{70}$ and a wide range of vertical restraints. ${ }^{71}$

The broad acceptance of per se rules of illegality in this period reflected two related concerns. First, the Supreme Court, perhaps reflecting upon the open-ended formulation it had endorsed in Chicago Board of Trade, ${ }^{72}$ came to perceive the rule of reason to be a terribly difficult standard to apply in practice. As the Court explained in 1958 in Northern Pac. Ry. Co. v. United States, ${ }^{73}$ a rule of per se illegality sidestepped these burdens: "This principle of per se

66 United States v. Trenton Potteries Co., 273 U.S. 392 (1927).

67 Appalachian Coals v. United States, 288 U.S. 344 (1933). The Court distinguished the case from Trenton Potteries, pointing out that the defendants in the latter case accounted for 82 percent of the relevant market, whereas the market share of the defendants in Appalachian Coals had roughly 12 percent. 288 U.S. at 375.

68 In Socony-Vacuum note 24, at 223 the Court said: "Under the Sherman Act, a combination formed for the purpose and with the effect of raising, depressing, fixing, pegging, or stabilizing the price of a commodity in interstate or foreign commerce is illegal per se." The Court quickly qualified this observation by disavowing the need to prove anticompetitive effects; all price-fixing agreements were "banned because of their actual or potential threat to the central nervous system of the economy." Id. at $224 \&$ n. 59.

69 Topco note 44, at 608-10; Timken note 24, at 597-98.

70 Klor's Inc. v. Broadway-Hale Stores, Inc., 359 U.S. 207, 212 (1959).

71 Albrecht v. Herald Co., 390 U.S. 145, 152-54 (1968) (maximum RPM); Schwinn note 24, at 379 (vertical territorial restrictions).

72 In Chicago Board of Trade, note 18, at 238, the Court provided a formidable description of the content of a reason analysis: The court "must ordinarily consider the facts peculiar to the business to which the restraint is applied; its condition before and after the restraint was imposed; the nature of the restraint and its effect, actual or probable. The history of the restraint, the evil believed to exist, the reason for adopting the particular remedy, the purpose or end sought to be obtained, are all relevant facts."

73356 U.S. 1 (1958). 
unreasonableness . . . avoids the necessity for an incredibly complicated and prolonged economic investigation into the entire history of the industry involved, as well as related industries, in an effort to determine at large whether a particular restraint has been unreasonable - an inquiry so often wholly fruitless when undertaken." ${ }^{74}$ Second, the Court indicated that it was incapable of performing the more elaborate analysis, especially the assessment of economic arguments, that the rule of reason appeared to require. ${ }^{75}$

By the early 1970s, US jurisprudence portrayed the analytical choices available under Section One as sharply dichotomous: a quick, administrable rule of per se illegality, or a hopelessly complex reasonableness standard that was likely to exculpate defendants. This portrayal provided no recognition that the broad application of the per se rule might entail significant efficiency losses, or that intermediate methods might be developed to make a more elaborate analysis manageable.

Since the mid-1970s, the Court has revisited these assumptions - with dramatic effects. It has concluded that various practices once subject to categorical prohibition yielded important economic benefits in too many cases to be condemned out of hand, and it identified ways in which a more elaborate assessment could be undertaken without recourse to the indeterminate inquiry suggested by Chicago Board of Trade. Pronounced concerns with overinclusiveness and greater confidence in administrability inspired the shift documented above: the withdrawal of numerous forms of behaviour from the class of matters worthy of categorical prohibition, ${ }^{76}$ and the replacement of the dichotomy model of Section One with a continuum in which per se liability and fuller reasonable inquiries are linked by intermediate tests called quick look or truncated forms of analysis -- that permit a phased, structured examination of evidenced bearing on efficiency justifications. ${ }^{77}$

\section{Rules of per se illegality}

Consistent with the approach anticipated in Standard Oil in 1911 and reinforced in SoconyVacuum and later decisions, US courts today apply a rule of per se illegality rule for agreements that are deemed to have harmful effects in the typical case. As suggested above, the decision about what to place in the category of per se illegality requires a judgment about how often observed conduct has harmful effects. US doctrine now reserves this approach mainly for horizontal agreements (including price fixing, schemes to allocate customers or geographic regions - unless ancillary to a collaboration that enhances efficiency) and not for conduct with more ambiguous consequences, such as vertical agreements, ${ }^{78}$ mergers and single-firm exclusionary behaviour. In principle, the category could be expanded to include other forms of conduct which theory and experience show to have, or almost always have, harmful effects. The Supreme Court has indicated that the expansion of the category depends partly on the extent of "experience" that courts have had with the practice, ${ }^{79}$ yet its decisions

74 Id. at 5.

75 Topco note 44 , at $609-10$ \& n. 10 (cautioning against a "ramble through the wilds of economic theory in order to maintain a flexible approach").

76 See Continental TV, Inc. v. GTE Sylvania Inc., 433 U.S. 36 (1977), State Oil, note 26, and Leegin note 8.

77 See NCAA, note 28, Federal Trade Commission v Indiana Federation of Dentists 476 U.S. 447 (1986), Polygram, note 28; cf. cite to California Dental,

78 See notes 89-98 and text.

79 Arizona v. Maricopa County Medical Society, 457 U.S. 332, 344 (1982) (“Once experience with a particular kind of restraint enables the Court to predict with confidence that the rule of reason will condemn it, it has applied a conclusive presumption that the restraint is unreasonable."). 
do not discuss the quantum of necessary experience, nor do they identify the process by which a court should conclude that the requisite critical mass of experience has been achieved.

As already outlined an important development in the US has accompanied the refinement of the category of behaviour worthy of summary condemnation through the incorporation of an initial classification step based on the Addyston Pipe ancillarity framework. ${ }^{80}$ In 1979 in Broadcast Music, Inc. v. Columbia Broadcasting System, Inc. ("BMI"), ${ }^{81}$ the Supreme Court brought characterization out of the shadows and recognized it as the inevitable starting point of a Section One inquiry. ${ }^{82}$ The blanket copyright licenses at issue in $B M I$, literally taken, were agreements to fix prices, yet the Court said this fact by itself did not mean that the agreements warranted per se condemnation. Before it decides that conduct belongs in a category of activity subject to per se prohibition, it must ask whether the defendants had a cognizable business justification. ${ }^{83}$ To characterize the conduct, the court asks two related questions. First, is the practice "plainly anticompetitive" in the sense that it "facially appears to be one that would always or almost always tend to restrict competition and decrease output? ${ }^{84}$ Second, is the practice at issue "designed to increase economic efficiency and render markets more, rather than less, competitive"? ${ }^{85} B M I$ thus abandoned the notion that the Section One analytical framework posits a sharp dichotomy between per se illegality and a full-blown rule of reason. As noted below, this development was followed by several Supreme Court decisions - notably, $N C A A^{86}$ and Indiana Federation of Dentists ${ }^{87}$ - that endorsed intermediate forms of scrutiny as alternatives to a full-blown rule of reason inquiry.

The analysis in $B M I$ raises the possibility that the label of per se illegality itself is a misnomer. As Thomas Krattenmaker has pointed out, BMI contemplates that the defendant always has an opportunity to present what the courts regard to be cognizable justifications, such as the value of a challenged restraint in facilitating cooperation that leads to the introduction of a new product that would not be available without cooperation and the facilitating restraint. ${ }^{88}$ Professor Krattenmaker makes a persuasive argument that the Court has not established rules of per se illegality so much as it has declared certain defences to be per se unacceptable. By this view, the courts have specified a range of defences that so not entitle the defendants to a more elaborate inquiry. In terms of the $B M I$ framework, the

80 See note 65 and text.

81441 U.S. 1 (1979).

82 One year earlier, in National Society of Professional Engineers v. United States, 435 U.S. 679 (1978), the Supreme Court had anticipated the characterization approach endorsed in BMI. The Court began its review of the professional society's code of ethics by observing that the restriction at issue "operates as an absolute ban on competitive bidding" and noting that "no elaborate industry analysis is required to demonstrate the anticompetitive character of such an agreement." 435 U.S. at 692. The Court then considered and rejected the society's "affirmative defense" that competitive bidding would lead professional engineers to skimp on quality and design structures that endangered public safety. Id. at 693, 696.

83 Id. at 8-9.

84 Id. at $19-20$.

85 Id. at 20.

86468 U.S. 85 (1984).

87476 U.S. 447 (1986).

88 Thomas G. Krattenmaker, Per Se Violations in Antitrust Law: Confusing Offenses with Defenses, 77 Geo. L.J. 165 (1988). 
defendants are not entitled to a fuller review if they argue, in the characterization process, that they set reasonable prices, that competition deprives them of needed levels of profitability, that they lack market power needed for an output restriction to affect prices, that they restricted rivalry with regard to a more popular product as a means to encourage consumers to purchase more of a product they regarded as inferior, or that they never actually implemented their output restriction scheme.

The express recognition of characterization as a way to test efficiency claims at the threshold of Section One analysis and the development of intermediate methods to apply the rule of reason did not resolve enduring concerns that courts - including the Supreme Court - had about the application of per se rules that had survived the retrenchment that took place after the early 1970s. One concern was that one of the rules of per se illegality - the ban on resale price maintenance ("RPM") established in 1911 in Dr Miles Medical Co v John D Park \& Sons $\mathrm{Co}^{89}$ - was excessively overinclusive in its tendency to forbid arrangements that had important redeeming competitive features. For nearly a century, the Court sought to confine the reach of the Dr. Miles rule, not directly by altering the substantive test itself, but indirectly through equilibration by manipulating the definition of agreement in the RPM context.

The first equilibration move came in United States $v$ Colgate \& $C o^{90}$ in 1919, when the Court ruled that no agreement was formed if the manufacturer announced its refusal to deal with discounters and proceeded to terminate any retailer that deviated from its policy. Sixty years later, in deciding in Continental T.V. Inc. v. GTE Sylvania, Inc. ${ }^{91}$ that non-price vertical restraints were to be governed by the rule of reason, the Court expressly disavowed any intent to tamper with the per se prohibition for RPM. As the personal papers of Supreme Court Justice Lewis Powell indicate, ${ }^{92}$ the Court considered the possibility in Monsanto Co v SprayRite Serv Corp $^{93}$ in 1984 of taking the step it had foregone in Sylvania: to eliminate the per se ban on RPM. Fearing that repudiation of Dr. Miles would lead Congress to amend Section One to ban RPM categorically, the Court pursued another strategy. First in Monsanto and later in Business Electronics,${ }^{94}$ the Court left the rule of Dr. Miles in place but heightened the proof that plaintiffs must introduce to demonstrate the existence of an agreement to set a resale price. Through this form of equilibration, the Court eroded the impact a per se rule it perceived to be unwise by making it more difficult for plaintiffs to establish the key predicate to a successful suit - that the defendant had formed an agreement to set resale prices. In a separate line of cases, the Court ruled that the private plaintiff could not recover damages for an admitted instance of minimum RPM unless it showed that the challenged conduct reduced competition. ${ }^{95}$ This application of the antitrust injury requirement recognized in Brunswick

89220 U.S. 373 (1911).

90250 US 300, 307 (1919)

91433 U.S. 36 (1977).

92 Andrew I. Gavil, A First Look at the Powell Papers: Sylvania and the Process of Change in the Supreme Court, Antitrust, Fall 2002, at 8.

93465 US 752 (1984).

94 Business Electronics, note 25.

95 Atlantic Richfield Co. v. USA Petroleum Co., 495 U.S. 328 (1990). 
Corp. v. Pueblo Bowl-O-Mat, Inc. ${ }^{96}$ in 1977 had the effect of converting a per se offense into a reasonableness analysis with respect to the entitlement to monetary relief.

In Leegin Creative Leather Prods., Inc. v. PSKS, Inc. ${ }^{97}$ the Court finally focused directly on the substantive rule of per se illegality, overturned the principle of Dr. Miles, and made minimum RPM a rule of reason offense. ${ }^{98}$ As noted below, responding to administrability concerns raised by Justice Breyer's dissent, the Court majority took some steps to suggest how a rule of reason might be applied to RPM in the future and thus preserve a genuine means for policing competitively harmful applications of the practice.

A second form of judicial equilibration has involved the ban on horizontal output restrictions. In the modern era, the Supreme Court has not wavered from the principle that horizontal price-fixing, customer allocations, and territorial divisions, if unrelated to an integration of effort that yields efficiencies, warrant per se condemnation. Nonetheless, the Court has expressed repeated concerns that the use of private rights of action in the US system (which feature mandatory trebling of damages, fee recovery by victorious plaintiffs, availability of class actions, jury trials, joint and several liability, and recourse to extensive discovery tools) presented a serious risk of overdeterrence in horizontal restraints cases and in matters involving single-firm conduct. In Matsushita Elec. Indus. Co., Ltd. V. Zenith Radio Corp. ${ }^{99}$ in 1986 and Bell Atlantic Corp. v. Twombly ${ }^{100}$ in 2006, the Court heightened the tests that plaintiffs must satisfy to plead and prove concerted action. In doing so, the Court has made it more difficult for plaintiffs to avail themselves of a nominally powerful rule of liability.

A subject of continuing controversy is the continuing habit of US courts to use the terminology of per se illegality to condemn certain tying arrangements. In Jefferson Parish Hosp. Dist. No. 2 v. Hyde, ${ }^{101}$ the court majority rejected the suggestion of the four concurring justices that the per se label badly fit a rule that required a showing of market power in the tying product to establish the defendant's capacity to coerce buyers to acquire the tied product, as well. ${ }^{102}$ The majority said that it was too late in the Court's jurisprudence to suggest that tying was not per se illegal. One can confidently anticipate that, in light of developments described above, that the Supreme Court in a future tying case will take the opportunity to change the vocabulary it has used to describe the tying offense. One possibility is to say that tying is evaluated with a structured rule of reason that uses, among other techniques, a market power screen to determine liability and an assessment of efficiency justifications.

\footnotetext{
96429 U.S. 477 (1977).
}

97551 U.S. 877 (2007).

98 Nearly a decade earlier, in State Oil, note 26, the Court had eliminated per se condemnation for maximum RPM schemes. The Court could have, but did not, apply a variant of BMI to RPM by retaining per se condemnation for applications of RPM that posed serious competitive dangers, yet still allowing defendants, as part of a threshold characterization process, to advance cognizable efficiency justifications.

99 Matsushita, note 25.

100 Twombly, note 25.

101466 U.S. 2 (1984).

102 The publicly available papers of Justice Thurgood Marshall reveal Justice Sandra Day O'Connor's futile attempt to persuade Justice John Paul Stevens and his colleagues in the majority that the "per se" label badly fit the hybrid test that the Court had applied to tying arrangements. William E. Kovacic, Antitrust in the O'Connor-Rehnquist Era: A View from Inside the Supreme Court, Antitrust, Summer 2008, at 21, 24-25. 
Before departing from our discussion of the per se rule of illegality in US jurisprudence, we underscore the dangers of relying on indirect methods such as equilibration to address imperfections in the substantive rule itself. The manipulation of the agreement requirement to offset perceived overinclusiveness in the per se rule of Dr. Miles introduced serious, enduring distortions into US jurisprudence. Concepts used to cabin the reach of what the Court perceived to be an improvidently broad legal command for RPM (per se illegality) have shaped the definition of agreement more generally and have arguably undermined the effectiveness of a wisely cast ban on various horizontal restraints. ${ }^{103}$ This tendency in US cases demonstrates an important hazard of resorting to bright-line rules to condemn conduct with ambiguous competitive effects. Perceiving the imperfections of the bright-line rule, courts for various reasons may be reluctant to reformulate the substantive rule itself and instead may turn to second-best solutions (e.g., equilibration) that distort the application of the law and rob the system of its coherence.

As described above, the trend in modern US jurisprudence has been to reduce the number of offenses deemed to be illegal per se. This does not mean that the category could not be expanded in the future. Within the field of horizontal restraints, the courts since Socony have expanded the range of restrictions that fall within the general prohibition of behaviour that amounts to price-fixing. The offense includes not only the establishment of output levels or ultimate prices, but also agreements to use only certain types of inputs, to fix credit terms, to forego advertising, or to refuse to engage in competitive bidding. ${ }^{104}$ Decisions have cautioned that admission into the per se category must be based on assessments of a practice's "demonstrable economic effect," 105 and it is safe to say, based on the Supreme Court's recent analysis of "reverse payments" in the pharmaceutical sector, ${ }^{106}$ that the expansion of the per se illegal category will not be easily accomplished. Nonetheless, one can imagine that future decisions might extend the per se ban to practices that are shown to have dangerous competitive effects and seldom present efficiency justifications. One candidate is the use of "no-poaching" agreements by which firms restrict competition for talented employees. ${ }^{107}$

\section{Rules of Per Se Legality or Safe Harbours?}

Professor Crane and other commentators have argued that antitrust policy should be attentive to possibilities for declaring practices to be per se legal when the conduct trends to have beneficial or benign competitive effects and efforts to police the behaviour with antitrust oversight poses serious risks of discouraging the conduct in the first place. US jurisprudence can be said to have embraced this proposition, at least to some extent. Examples would include the Colgate protection in the RPM disputes for purely "unilateral" efforts by a manufacturer to state a policy of no-discounting and of terminating retailers who violate it;

103 This development is analyzed in Gavil et al., note 12, at 335, 338-40.

${ }^{104}$ Id. at 42-80 (documenting the extension of the ban on price-fixing to related practices).

105 This is the phrase the Supreme Court used in Sylvania to describe nonprice vertical restraints worthy of summary condemnation. Sylvania, 433 U.S. at 59.

106 Federal Trade Commission v. Actavis, Inc., 133 S.Ct. 2223 (2013) (reverse payments concern patent settlement agreements involving payments by the patentee to the alleged infringer. Often they do not involve the transfer of technology, but are based on a value transfer from one party in return for a limitation on the entry and/or expansion on the market of the other.)

107 Department of Justice \& Federal Trade Commission, Guidance for Human Resources Professional 4 (Oct. 2016) ("Going forward, the DOJ intends to proceed criminally against naked wage-fixing or no-poaching agreements.”), available at http://www.justice.gov/atr/file/90354/download. 
the general immunity from predatory pricing claims that firms enjoy if they set their prices above their total costs; and other decisions that suggest US law does not reach price squeeze claims or refusals to license intellectual property. ${ }^{108}$ One can also point to the use of market share screens in the application of the rule against tying. A further example, in the realm of public merger enforcement policy, is the use of safe harbours to exempt from challenge transactions below certain HHI thresholds. ${ }^{109}$

In addition to more formalized safe harbours, one can say that actual patterns in enforcement and adjudication make clear that firms are unlikely to incur liability (though they may occasionally have to litigate to avoid it) for certain types of practices. Researchers have documented that, since Sylvania, defendants have won an overwhelming share of all litigated nonprice vertical restraint disputes. ${ }^{110}$ Agency enforcement prioritisation also has played an important role in determining the number of litigation events. The US federal agencies have prosecuted no Robinson-Patman Act price discrimination claims since $2000 .{ }^{111}$ In 1976, the Justice Department declared that it would not enforce the statute, even though one section of the Robinson Patman Act provides criminal sanctions which DOJ alone can seek. ${ }^{112}$

\section{E. Rule of Reason Analysis}

Modern US jurisprudence has responded to the concern, which motivated expanded recourse to rules of per se illegality between 1940 and the early 1970s, that the rule of reason as conceived in Chicago Board of Trade was an intolerable administrative burden for courts and a near-guarantee of pro-defendant outcomes. In general terms, lower court decisions in the US have identified essentially three stages to a reasonableness analysis: ${ }^{113}$

- Stage One: The plaintiff bears the initial burden of producing evidence tending to show that the challenged conduct has anticompetitive effects. The plaintiff can meet this burden in various ways, depending on the quality of evidence indicating competitive harm.

- Stage Two: Once the plaintiff produces evidence tending to demonstrate anticompetitive effects, the burden shifts to the defendant to present a cognizable justification for its conduct. Where the probability of harm is high, and the likelihood of a suitable justification is low, the presumption of harm becomes irrebuttable. Otherwise, the defendant can rebut the plaintiff's case either by contesting evidence used to create a

${ }^{108}$ Crane, Rules Versus Standards, note 7.

109 Gavil et al., note 12.

${ }^{110}$ See e.g., Douglas H. Ginsburg, Vertical Restraints: De Facto Legality Under the Rule of Reason (1991) 60 Antitrust Law Journal 67 and Mark A. Patterson, The Role of Power in the Rule of Reason, 68 Antitrust L.J. 429 (2000). See also Valley Liquors, Inc. v. Renfield Importers Ltd., 678 F.2d 742, 745 (7 ${ }^{\text {th }}$ Cir. 1982) and Rothery Storage \& Van Co. v. Atlas Van Lines, 792 F.2d 210 (D.C. Cir. 1986), Judge Bork suggested that a low market share ( $6 \%$ of nationwide sales) could serve as an indication that market power was lacking, and the imposition of vertical restraints as part of a legitimate horizontal joint venture could not injure competition.

${ }^{111}$ Daniel Sokol, Analyzing Robinson-Patman, 83 Geo. Wash. L. Rev. 2064, 2066-67 (2015).

112 Id. The FTC continued to enforce the statute, although the number of prosecutions fell in the subsequent decades. The most recent FTC case was filed in 2000.

${ }^{113}$ This description is adapted from Gavil et al., note 12, at 141-52. The plaintiff bears the ultimate burden of persuasion with respect to all elements of the challenged antitrust offense. See Gavil, note 38. 
presumption of competitive harm, or by introducing evidence that the conduct is benign or procompetitive.

- Stage Three: If both parties have met their respective burdens in Stages One and Two, the court will assess all of the evidence to determine whether the plaintiff's hypothesis of harm is more likely than not. This phase sometimes is referred to as "balancing." In performing this third stage, some courts have considered whether the defendant's valid procompetitive justifications could have been accomplished by recourse to less competitively restrictive means. The criterion of less restrictive alternatives (LRAs) was developed chiefly in the identification of ancillary restraints, but its modern application has not been limited to such cases and now can be seen as one element of a structured rule of reason inquiry.

Two decisions in the 1980s set the foundation for the modern framework by recognizing intermediate alternatives to summary condemnation and a full-blown rule of reason inquiry. In National Collegiate Athletic Ass'n v. Board of Regents of the University of Oklahoma, ${ }^{114}$ the Supreme Court concluded that when the presence of plausible, cognizable efficiency justifications precluded summary prohibition under the per se rule, a full rule of reason analysis was not invariably necessary. Sometimes a restraint's competitive harm will be apparent from an abbreviated reasonableness analysis that avoids an inquiry, for example, into the defendant's market power; ${ }^{115}$ "when there is an agreement not to compete in terms of prices or output, "no elaborate industry analysis is required to demonstrate the anticompetitive character of such an agreement." 116 The Court considered the defendant's efficiency claims, but did so in the framework of a truncated analysis. It rejected the assertion that the challenged restrictions were needed to shield an inferior product from competition from a superior product, and it held that justifications for an otherwise unlawful restraint must be reasonably "tailored" to achieve a procompetitive aim. ${ }^{117}$

Two years later, in Federal Trade Commission v. Indiana Federation of Dentists (IFD), ${ }^{118}$ the Supreme Court again recognized the existence of "quick look" or "truncated" variants of the rule of reason. The Court held "no elaborate industry analysis is required to demonstrate the anticompetitive nature" of an agreement among members of a dental society to refuse to provide $\mathrm{x}$-rays to insurers who were processing claims on behalf of consumers of dental care. ${ }^{119}$ The Court explained: "Absent some countervailing procompetitive virtue - such as, for example, the creation of efficiencies in the operation of a market or the provision of goods and services - such an agreement limiting consumer choice by impeding the 'ordinary give and take of the market place,' . . . cannot be sustained under the Rule of Reason. ${ }^{120}$

\footnotetext{
114468 U.S. 85 (1984).

115 The delineation of a relevant market and the measurement of market power often are the two exercises that give the full-blown rule of reason its elaborate character. Techniques that bypass these processes can simplify antitrust litigation substantially.

116468 U.S. at 109. The Court observed that the rule of reason "can sometimes be applied in the twinkling of an eye." Id. at 110 \& n. 39.

117468 U.S. at 113-19.

118476 U.S. 447 (1986).

119 Id. at 459.

${ }^{120}$ Id.
} 
As a group, BMI, NCAA, and IFD indicated that the assessment of horizontal agreements occurs along an analytical continuum in which the court evaluates behaviour in a level of detail necessary to comprehend its competitive effects. In 1992 in California Dental Association v. Federal Trade Commission, ${ }^{121}$ the Supreme Court expressly acknowledged that its earlier cases recognized an abbreviated or "quick look" variant of the rule of reason. ${ }^{122}$ The Court underscored the trend toward a continuum, rather than dichotomous, model of analysis: "The truth is that our categories of analysis of anticompetitive effect are less fixed than terms like 'per se,' 'quick look,' and 'rule of reason' tend to make them appear." 123 The elaborateness of the analysis depended on context: "As the circumstances here demonstrate, there is generally no categorical line to be drawn between restraints that give rise to an intuitively obvious inference of anticompetitive effect and those that call for more detailed treatment. What is required, rather, is an enquiry meet for the case, looking to the circumstances, details, and logic of a restraint." 124

The Court's modern decisions have provided limited guidance about how the new conception of the rule of reason should be applied, and how, in particular, abbreviated variants are to be structured. Lower court decisions have sought to add this analytical architecture. A noteworthy example is the court of appeals decision in Polygram Holding, Inc. v. Federal Trade Commission, ${ }^{125}$ which endorsed a truncated analysis framework employed by the FTC to assess restrictions that rival record labels had imposed upon each other in connection with the introduction of a commonly produced concert recording. In the Polygram framework, the plaintiff begins by demonstrating that that conduct is "inherently suspect" in its obvious tendency, based on a survey of its character and its similarity to other restraints found to present serious competitive dangers. The defendant then must come forward with plausible, legally cognizable justifications for the behaviour. If the defendant provides such justification evidence, the plaintiff then must explain why the court may conclude, without further evidence, that anticompetitive effects are likely to predominate, or to provide evidence suggesting that such an outcome is likely. If the plaintiff meets this burden, the evidentiary burden shifts to the defendant to show that the restraint does not harm consumers or has net procompetitive virtues. The plaintiff bears the ultimate burden of persuasion in establishing all elements of the offense.

In a general way, Polygram's burden-shifting approach resembles the framework that the same court used to decide the monopolization suit prosecuted by the Justice Department against Microsoft. ${ }^{126}$ There the Court described the Section Two inquiry as having the following basic steps. ${ }^{127}$ The plaintiff first presents a theory of anticompetitive harm (which typically entails a demonstration that the defendant possesses substantial market power), and the defendant then offers justifications for its behaviour. If the parties have presented a mix of procompetitive and anticompetitive evidence, the court then balances the proof to determine liability.

\footnotetext{
121526 U.S. 756 (1999).

122 Id. at 770-71.

123 Id. at 779 .

124 Id. at 780-81.

125416 F.3d 29 (D.C. Cir. 2005).

${ }^{126}$ United States v. Microsoft Corp., 253 F.3d 34r (2001) (per curiam).

${ }^{127}$ For a summary and graphical representation of this framework, see Gavil et al., note 12, at 555-56.
} 
One area that begs for future application of these or similar frameworks is RPM. In Leegin, the Supreme Court did not simply take minimum RPM out of the per se illegality compartment but went on to describe four scenarios in which RPM might be harmful and spelled out three criteria to be used to identify harmful applications of the restraint. ${ }^{128}$ The US federal agencies have done little to develop a framework for applying this guidance in practice. Following Leegin in 2007, the DOJ and the FTC have prosecuted no RPM cases. ${ }^{129}$ Their only contributions to the elaboration of a post-Leegin analytical framework have consisted of an FTC decision in 2008 to modify an RPM order premised on a per se illegality theory before Leegin, and a DOJ speech in 2009 on the application of the rule of reason to RPM in the future. ${ }^{130}$ Given its capacity to use administrative adjudication, the FTC would be an appropriate forum in which to discuss how to apply the rule of reason to RPM in the postLeegin world.

In all matters involving agreements, the courts have taken few opportunities to address the relationship between the characterization process, the rule of reason and the concept of ancillarity introduced in Addyston Pipe and still referred to today in joint venture analysis. ${ }^{131}$ Gregory Werden's interpretation of recent cases finds that when a restraint is deemed to be reasonably necessary to achieve the venture's legitimate aims, the rule of reason is then applied to assess the competitive significance of venture and the collateral restraint as a package. ${ }^{132}$ This provides significant protection for restraints imposed to execute the core functions of a legitimate venture. ${ }^{133}$ When, however, a restraint is deemed not to be collateral to the performance of such core functions, it is analysed separately from the venture.

A related point involves the concept of LRAs and how it builds upon or extends the principle of ancillarity. The LRA concept embodies a principle of proportionality that might be exemplified in a burden shifting approach, especially to test the defendant's reasonable business justifications. There is considerable contemporary debate about how to apply the LRA concept and, more generally, to engage in the balancing of anticompetitive harms and procompetitive benefits that is the final potential stage of the rule of reason in a burdenshifting approach. ${ }^{134}$ A frequently expressed fear is that the application of the LRA test invites indeterminate ex post speculation about how the defendants might otherwise have

${ }^{128}$ Leegin, 551 U.S. at 892-94, 897-98.

${ }^{129}$ William E. Kovacic, The United States and Its Influence on Global Competition Policy, 22 Geo. Mason L. Rev. 1157, 1201-02 (2015)

${ }^{130} \mathrm{Id}$.

${ }^{131}$ Gregory J. Werden, Two Missed Opportunities With the Competitor Collaboration Guidelines, Antitrust, Summer 2016, at 56.

132 Id. at 57 (discussing In re Ins. Brokerage Antitrust Litig., 618 F.3d 300 (3d Cir. 2010) and Major League Baseball Props., Inc. v. Salvino, Inc., 542 F.3d 290 (2d Cir. 2008)).

133 See Texaco Inc v Dagher 547 US 1 (2006) and American Needle, Inc v National Football League 560 US 183 (2010), Alan Devlin and Michael Jacobs, Joint-Venture Analysis After American Needle (2011) 7(3) J Competition L \& Economics 543 and Alison Jones, Drawing the boundary between joint and unilateral conduct: parent-subsidiary relationships and joint ventures in RESEARCH HANDBOOK ON INTERNATIONAL COMPETITION LAW (ed Ariel Ezrachi).

${ }^{134}$ Actual balancing under the rule of reason in antitrust cases is a rare occurrence. Michael A. Carrier, The Rule of Reason: An Empirical Update for the 21 $1^{\text {st }}$ Century, 16 Geo. Mason L. Rev. 827 (2009). See also Scott Hemphill, Less Restrictive Alternatives in Antitrust Law, 116 Colum. L. Rev. 927 (2016) (describing how assessment of less restrictive alternatives could provide structure to the balancing stage of the rule of reason). 
achieved their aims, with inadequate consideration of the options realistically available to the firms as they designed their strategy ex ante.

\section{F. Summary and Impact of the Enforcement System}

As suggested above, there are important links between the development of horizontal restraints analysis and the design of the US enforcement regime. First, the development of a criminal enforcement regime creates strong pressure to recognize per se illegality as a distinct, well-defined category of infringement. This works against attempts to depict the rule of reason as a continuum rather than a sharply dichotomous mechanism. In the US, DOJ has demanded recognition of a category of per se illegal offenses to assist in persuading juries and judges that certain behaviour deserves criminal punishment, especially the incarceration of individuals. Since the early 1980s, DOJ has focused criminal enforcement solely upon horizontal price-fixing, market and customer allocations, and related schemes. DOJ, and perhaps other prosecutors, dislike the notion that there is a "continuum" of illegal conduct, instead of a sharp dichotomy between acts always forbidden and acts sometimes allowed.

Second, judicial perceptions about overreaching in the US system of private enforcement have induced significant efforts at equilibration in the form of heightened evidentiary and pleading standards that private plaintiffs must meet in order to invoke rules of per se liability. We do not assert that the judicial perceptions have sound empirical foundations; we do conclude that the perception exists. The fact of extensive equilibration, along with the distortions it can produce in antitrust doctrine, suggests an urgent need to determine, as an empirical matter, whether concerns about overdeterrence are well founded, and how the effects of overdeterrence match up with the benefits generated by the status quo private rights mechanism. To the extent that such concerns have a strong empirical basis, the solution likely rests in refinements of the private rights process that have been shown to cause overdeterrence. If further study shows the empirical basis to be lacking, the courts and enforcement agencies should take steps to unwind the equilibrating devices established to address perceived overdeterrence.

Third, concerns about the capacity and expertise of the courts to deal with analytical complexities posed by the rule of reason might be resolved through greater use of the FTC's administrative process to adjudicate cases. This would expand the FTC's role in what Professor Crane has called "norms creation." 135 By this approach the FTC would play a larger role in the litigation of Section One cases with an eye toward applying its economic expertise to identify the form of inquiry suitable for individual restraints and to experiment with different methods for organizing the presentation and assessment of evidence. Well-reasoned FTC decisions would provide templates for possible adoption by the federal courts.

\section{ANALySis In The EURopean Union}

\section{A. The Goals of EU competition law}

One impediment to the creation of a clear framework of antitrust analysis in the EU is that the objectives of the competition rules are not clearly articulated. On the contrary, although they have undoubtedly evolved, they remain keenly contested.

Since the end of the 1990s, the Commission has pursued the view that antitrust analysis is, or should be, underpinned by a consumer welfare objective and that this should be reflected in the interpretation of key terms such as "restriction" of competition (Article 101(1)),

135 Daniel A. Crane, The InSTITUTIONAL StRUCTURE OF ANTITRUST ENFORCEMENT (Oxford 2011). 
"improving the production or distribution of goods" and "promoting technical or economic progress" (Article 101(3)). Many Commission documents and guidelines now state that its inquiry under the three antitrust pillars focuses on consumer harm and consumer welfare within a similar structure for assessment involving: ${ }^{136}$

1. Demonstration of anticompetitive effects (actual, likely or assumed ${ }^{137}$ ) in terms of parameters of competition (such as price, product quality or choice, innovation) ${ }^{138}$

2. A balancing/ weighing of potential anticompetitive effects with likely efficiencies. ${ }^{139}$

Although the Commission has always played a central role in enforcing EU competition law and in developing competition policy, it is the Court of Justice of the European Union which is charged with responsibility for interpreting EU law. ${ }^{140} \mathrm{~A}$ number of EU court judgments rely upon mainstream economic tools to shape and interpret EU competition law and have placed emphasis on the welfare of consumers within them. ${ }^{141}$ It cannot be said, however, that the case law unambiguously endorses consumer welfare as the ultimate objective of EU competition law. ${ }^{142}$ Rather, it has been guarded about ranking consumers' interests over others. Indeed, some judgments of the EU courts have accepted that public policy objectives may override, or must be weighed against, the impact of conduct on competition and consumers, ${ }^{143}$ and numerous cases have stressed the importance of the competition rules in ensuring the integration of national markets and protecting the structure of competition within the EU. ${ }^{144}$

The prominence attached in the cases to the single market objective ${ }^{145}$ is frequently raised as a factor which distinguishes EU competition law from other systems and some cases

136 Esteva Mosso, note 15.

137 An important difference between Arts 101/102 and merger analysis, however (apart from the respective expost/ ex -ante nature of the reviews) is that "hard-core restrictions and restrictions 'by object' under Article 101 TFEU (which often, though not always, overlap) or "naked restriction" under Article 102 TFEU have no equivalent in merger control", Esteva Mosso, note 15.

${ }^{138}$ Under Art 101(1) (restriction of competition), Art 102 (an abuse of a dominant position) and/or the EU Merger Regulation (unilateral or coordinated effects liable to result in a significant impediment to effective competition).

139 A defence is explicitly provided for in Art 101(3), recognised in the EUMR (recital 29) and has been read into Art 102 case-law through acceptance of objective justifications for otherwise abusive behaviour.

${ }^{140}$ See note 7 and text.

${ }^{141}$ Even if not stated to be the laws sole or core objective. In C-67/13 P, Groupement des Cartes Bancaires (CB) v. Commission EU:C:2014:2204, for example, the CJ placed emphasis on the poor allocation of resources to the detriment, in particular, of consumers that results from certain types of collusive behaviour between firms liable to infringe Art 101, see note 179 and text.

142 The placement of the competition laws in a Treaty with multi-faceted objectives has complicated the question of whether it is possible for the law to evolve into "antitrust law pure and simple", GUILIANO AMATO, ANTITRUST AND THE BOUNDS OF POWER 116 (1997).

${ }^{143}$ See notes $211,237,251$ and 252 and text.

144 See especially Case C-501/06 P, GlaxoSmithKline Services Unlimited v. Commission [2009] ECR I-9291, paras 61-63.

145 See e.g., Rein Wesseling, The Modernisation of EC ANTITRUst LAW (Hart Publishing, Oxford, 2000), 48-49 ("Initially... [t] he antitrust rules were not more than private counterpart to the rules, enshrined in Articles 28-30 EC [the rules on free movement of goods]. ... The first period ... saw the Commission enforcing the rules with constant reference to ensuring the free flow of goods, thus promoting market integration.") 
undoubtedly elevate this concern over competition ones. Nonetheless, as the single market project is about realising efficiencies that bring welfare benefits, it is not clear that this objective should have to pull in a different direction to a consumer welfare one. ${ }^{146}$ The weight attached in the cases to the structure of competition, however, has led to significant disagreement between (i) those who stress the importance of competition law as a mechanism for preserving competition, safeguarding consumer choice and ensuring firms' equal and undistorted access to the market; ${ }^{147}$ and (ii) those who adhere to the view that changes to the structure of the market are important only in so far as they are likely to harm competition and consumers. ${ }^{148}$ "This focus on consumer harm gives orientation and consistency to competition law enforcement, something that cannot be expected from the goal of preserving a certain (not defined) structure of the market or the goal of protecting the competitive process itself." 149

These conflicting views about goals underpin much of the controversy about how key provisions of Article 101 should be interpreted.

\section{B. Rules or Standards?}

Material differences between Article 101 and Section One of the Sherman Act are the former's bifurcated structure, its specific prohibition of restrictions by object as well as restrictions by effect ${ }^{150}$ and the fact that Regulation 1/2003 allocates the burden of proof as between the claimant (Article 101(1)) and defendant (Article 101(3)). ${ }^{151}$ Whilst Article 101(1) prohibits agreements which appreciably restrict competition (by object or effect), Article 101(3) provides that the prohibition can be declared inapplicable to any agreement which satisfies its four conditions: that the agreement achieves specified benefits; that a fair share of those benefits are passed on to consumers; that the agreement does not contain any indispensable restraints; and that it does not eliminate competition in respect of a substantial part of the products in question. A number of block exemption regulations ("BER"s) exempt certain categories of agreement from Article 101(1). Although agreements meeting the conditions of a BER are presumed to meet the Article 101(3) criteria (see D below), in other

${ }^{146}$ Indeed, see Guidelines on the application of Article 81(3) [now 101(3)] (“Art 101(3) Guidelines") OJ [2004] C 101/97, para 42.

${ }^{147}$ See e.g., P Behrens, The Ordoliberal Concept of "Abuse” of a Dominant Position and its Impact on Article 102 TFEU in Paul Nihoul and I Takahashi, ABUSE REgulation In COMPETITION LAw, Proceedings of the 10th ASCOLA Conference (2015).

148 Thus protecting the competitive process, and precluding hindrances to it, benefits consumers - that is, that protecting the market structure from artificial distortions is the best mechanism for protecting the interests of the consumer in the medium to longer term.

${ }^{149}$ Luc Peeperkorn, Conditional pricing: Why the General Court is wrong in Intel and what the Court of Justice can do to rebalance the assessment of rebate, Concurrences Journal 1 (2015), at 48.

${ }^{150}$ See notes 165-166 and text; see also Ben Smulders, The Bifurcated Approach and Its Practical Impact on the Establishment of Harm to Competition, in The Notion of Restriction of Competition 51 (Damien Gerard et al. eds., 2017) (describing two=prong assessment of practices under Articles 101 and 102); Luc Gyselen, What Makes an Agreement Anti-competitive: Lessons from the Past, in THE NOTION OF RESTRICTION OF COMPETITION 111, 114-21 (Damien Gerard et al. eds., 2017) (examining the "dualist structure of Article 101).

151 [2003] OJ L1/1, Art 2. 
cases those claiming the benefit of Article 101(3) have the burden of establishing, by means of convincing argument and evidence, that all four Article 101(3) criteria are satisfied. ${ }^{152}$

This structure means that the question of how restrictions of competition are identified at the Article 101(1) stage profoundly influences the role and scope of Article 101(3). Similarly the existence of Article 101(3) influences the question of what constitutes a restriction of competition. Finding the right function to be played by the two parts of Article 101 thus provides an important starting point to the development of rules and standards within them. The discussion below however, illustrates that this has not proved to be easy and has, rather, added to the complexities arising in this area. If, for example, the interpretation of a restriction of competition was to become an enquiry into the competitive significance of the agreement with categories of antitrust analysis developed within it (as in the US and as some EU case-law suggests), the question of what role is to be played by Article 101(3) would clearly have to be addressed; the Commission's view is that this approach is untenable as it renders Article 101(3) "otiose". 153

The Commission's initial approach, however, was also problematic. The Commission tended, arguably motived both by ideology and practicalities, ${ }^{154}$ to interpret the concept of a restriction of competition set out in Article 101(1) broadly to encompass many restraints on firms' economic freedom ${ }^{155}$ and/or ability to engage in cross-border trade, and to rely on Article 101(3) as the main vehicle for authorising agreements. ${ }^{156}$ This led to conceptual and practical problems that are well-known. At the core, concerns were that the analysis it conducted under Article 101(1) was "anaemic", "unpersuasive"157 and (combined both with the difficulty of gaining an individual exemption under the notification and exemption system created by Regulation 17 and the rigidity of the early block exemption regulations (BERs)) generated legal uncertainty and legal formalisms which risked the condemnation and deterrence of innocuous agreements or legitimate business practices (Type 1 errors). The methodology also led to different treatment of agreements with similar effect and eliminated "what should be the heart of the matter and antitrust (i.e. economics/law) substantive analysis of a particular agreement or practice, i.e. its competitive harms and benefits". ${ }^{158}$

152 Case T-168/01, GlaxoSmithKline [2006] ECR II-296, para. 235. The requirements are cumulative, see e.g., Case C-68/12, Protimonopolný EU:C:2013:71, paras. 31-34.

${ }^{153}$ For the view that Art. 101(1) could be used for adopting an "economic rule of reason" and Art 101(3) for applying a policy rule of reason, see Rein Wesseling, The Commission White Paper on Modernisation of EC Antitrust Law: unspoken consequences and incomplete treatment of alternative options (1999) 20 ECLR 420.

${ }^{154}$ A broad jurisdictional interpretation of Art.101(1) cemented the Commission's central role in the moulding and shaping of EU competition policy since it had the exclusive right to apply Art. 101(3) through the system of notification and exemption, see Reg. 17 [1959-1962] OJ Spec. Ed. 87, Arts. 9(1) and 4.

155 See e.g., Jonathan Faull and Ali Nikpay (eds.), THE EU LAW OF COMPETITION (3rd edn, Oxford University Press, 2014), 3.160-3.166 and Barry E Hawk, System Failure: Vertical Restraints and EC Competition Law [1995] 32 CMLRev 973.

156 See, eg Goodyear Italiana-Euram, [1975] OJ L38/10; Campari, [1978] OJ L70/69 para 7, part IIA.

157 See Hawk note 155.

158 id, 2.5 
Recognising the need for change, the Commission's modernization programme ${ }^{159}$ promised a move away from its previous approach to Article 101, to an effects-based one built on a consumer welfare foundation and dividing substantive, economic appraisal of agreements more equally between the two parts of Article 101. In order to achieve this, the Commission pledged more realistic, economic analysis under Article 101(1), introduced more flexible BERs and accepted the need for it to give up its monopoly over Article 101(3), ${ }^{160}$ paving the way for self-analysis by firms of their agreements and a fuller role to be played by the national competition authorities (NCAs) and the national courts in the enforcement process. In the Commission's view the substantive economic analysis to be conducted is to be divided between the two distinct parts of Article 101:

- Article 101(1) is about identifying restrictions on inter- or intrabrand competition (assumed in object cases - actual or likely in effect cases) (so moving away from its early approach which favoured freedom of individual traders over consumer welfare); and

- Article 101(3) is about identifying procompetitive effects (economic benefits and efficiencies) and balancing those within the structure of Article 101(3) against the anticompetitive effects identified under Article 101(1) (efficiencies are presumed to offset anticompetitive effects in relation to agreements satisfying the conditions of a BER).

This clarifies that there are no absolute rules of per se legality under Article 101 - even in cases where anticompetitive effects are assumed - as harmful agreements can always be justified at the Article 101(3) stage (but see discussion in Section C below). Further, that the Commission's view is that there should be no consideration of competing anti- and procompetitive effects of an agreement at the Article 101(1) stage. Rather, Article 101(1) is about identifying "harm" whilst Article 101(3) is for identifying "benefits" and determining whether the restraints are indispensable to their achievement and whether a fair share of the benefits are passed onto consumers etc.

It has already been seen that one obstacle to the modernization process is that the Commission's statement on goals has not received unequivocal support from the Court. ${ }^{161}$ In addition, the sections below illustrate that despite the promised reforms, some lack of clarity as to exactly how Article 101 analysis is to be conducted persists. First, there is still jurisprudence which suggests an interpretation of the concept of a restriction of competition within the meaning of Article 101(1) which is not easy to fit within the general structure laid out by the Commission above. Not only are there cases which undoubtedly require some of assessment of "benefits" to be conducted at the Article 101(1) stage, but others suggest noncompetition factors may still be influencing the interpretation of the concept of a restriction of competition and when such restrictions should be assumed. Second, although the

159 The modernization programme commenced in January 1997, with the adoption by the Commission of a Green Paper on Vertical Restraints in EC Competition Policy, COM(96) 721, which included an economic analysis of the impact of vertical restraints on competition. Its conclusions, and the debate which followed it, led to a new regime for agreements centred around more economic, flexible, overarching block exemptions, the publication of guidelines on appraisal of agreements, and the abandonment of the authorization and notification system and the removal of the Commission's exclusive jurisdiction over Article 101(3), see note 160 and text.

160 Regulation 1/2003, [2003] OJ L1/1.

161 See notes $142-144$ and text. 
Commission's exclusive right to adjudicate individually on Article 101(3) has been removed, BERs still remain a key feature of the EU system and operate as a "safe harbour" for a swath of agreements. Although these exemptions are now more rooted in economics and provide helpful legal certainty to firms, ${ }^{162}$ their very existence perpetuates the centrality of Article 101(3) within the Article 101 system and cloud the relationship between it and Article 101(1). Finally, as the system continues to rely heavily on presumptions about the impact of agreements on competition, relatively few cases are arising before the EU courts which require an assessment of whether an agreement has as its effect the restriction of competition and how those anticompetitive effects can be balanced against benefits raised under Article 101(3). The fundamental issue of how the competing competitive harms and benefits of an agreement can be assessed under Article 101 has not therefore been developed and clarified.

\section{Rules of illegality?}

\section{i. Restrictions of competition by object}

There are no rules of absolute illegality under Article 101, Article 102 or the EU Merger Regulation; all conduct demonstrated to produce restrictive or anticompetitive effects can be defended if evidence of offsetting benefits can be demonstrated (in the context of Article 101 this generally occurs within the structure set out by Article 101(3) ${ }^{163}$ ). There is, nonetheless, a category of conduct (under Articles 101 and $102^{164}$ ) which is strongly presumed to infringe the rules. In the context of Article 101, this is the case for agreements which are found to restrict competition by object. Such agreements are:

(a) "assumed" to restrict competition within the meaning of Article 101(1) - where the object of an agreement "reveals in itself a sufficient degree of harm to competition law" "165 no assessment of anticompetitive effects is required, or permitted; ${ }^{166}$ and

(b) according to the Commission, presumed not to satisfy the conditions of Article 101(3). The Commission equates object restraints with "hardcore" restraints which preclude the safe harbours of the BERs from applying ${ }^{167}$ and make it most unlikely that the agreement will individually satisfy the Article 101(3) criteria; it considers agreements of this nature (a) generally fail to create objective economic benefits, (b) do not benefit consumers and/ or (c) are unlikely to be considered indispensable to the attainment of any efficiencies created by the agreement in question (efficiencies generated can generally be achieved by less restrictive means). ${ }^{168}$

162 The BERs are set out in EU regulations which are directly applicable and their benefit can only be withdrawn prospectively, see note 216 and text.

163 But see notes 233-237 and text and Case C-501/06 P, GlaxoSmithKline note 144.

164 Although no mergers are assumed to produce anticompetitive effects, even where market shares or concentration ratios are very high (see e.g., Case T-79/12, Sun Chemical Group v. Commission EU:T:2013:635) and the wording and structure of Art 102 is very different to Art 101 (it does not refer to abuses by object or effect), a "mirror" approach to that adopted under Art 101 is in fact pursued under Art 102, see e.g., Peeperkorn note 149.

165 Case C-67/13P, $C B$ note 141, para. 57

166 See eg Case C-286/13 P, Dole Food Co Inc and Dole Fresh Fruit Europe v. Commission (Dole) EU:C:2015:184, paras. 111-135, Case C-8/08, T-Mobile [2009] ECR I-4529, para 31 and Art 101(3) Guidelines, para. 22.

167 See Section 4.D.

168 See e.g., Art 101(3) Guidelines, paras 46, 79, 105. 
An argument is often made that object restraints can, and should, be treated in a different way to rules of illegality as they are not per se infringements (as in the US); rather, it is possible for parties to justify such agreements under Article 101(3). Because there is a stark difference between this theory and the practical realities, however, it is submitted that object restraints should be approached in a similar way to restraints caught by a per se rule (and for that reason we discuss them in this section). First, there is very little existing jurisprudence which provides comfort to suggest that the presumption of illegality can ever be overcome, that is as to when agreements found to restrict competition by object may satisfy the four onerous conditions of Article 101(3) in practice. Further, it seems most unlikely that such guidance will emerge in the future. ${ }^{169}$ Second, the pass-on requirement of Article 101(3) essentially requires a balancing of anti- and procompetitive effects and it is unclear how parties can establish that demonstrated beneficial effects offset anticompetitive effects the nature and magnitude of which has not been established under Article 101(1) but only assumed. Third, as the chance of benefiting from Article 101(3) is remote and there is a risk of fines or other serious consequences if such an agreement is found to be incompatible with Article 101, firms generally perceive this conduct to be prohibited or at least extremely risky to pursue. It seems crucial therefore that the concept of a restriction of competition by object is approached with this reality in mind. If it not confined to agreements which have a high risk of harming consumer welfare, there is a clear danger that, as is the case for overinclusive rules of per se illegality, procompetitive arrangements will be prohibited and deterred.

\section{ii. Scope of the By Object Category}

\section{Identifying the object or precise purpose of an agreement}

Case law consistently reiterates that to determine whether an agreement reveals a restrictive object or purpose - that is a "sufficiently deleterious impact on competition" must be had inter alia to the content of its provisions, the objectives it seeks to ascertain and the economic and legal context of which it forms part". ${ }^{171}$ Importantly, in Groupement des Cartes Bancaires $(C B) \vee$ Commission ${ }^{172}$ the CJ stressed that, because a finding that an agreement restricts competition by object exempts the Commission (or other claimant) from its ordinary burden of demonstrating a restriction of competition, the category must be interpreted restrictively. It is reserved for agreements which inherently reveal a sufficient degree of harm to competition and is inappropriate for other cases where a more detailed

169 Since the abolition of the notification and exemption system it is rare for competition agencies to conduct detailed analysis of when an agreement may satisfy the conditions of Art 101(3). Indeed, most cases pursued by the Commission under Art 101 and have been object cases and the Commission has not adopted a final decision at all in relation to a vertical agreement since 2005. A flurry of non-infringement decisions providing clear guidance on the application of Art 101(3) to agreements incorporating "object" restraints seems unlikely.. Not only are NCAs not permitted to adopt non-infringement decisions, (see Case C-375/09, Tele2Polska [2011] ECR I-3055) but it seems improbable that the Commission will wish, or be able, to dedicate resources to adopting this kind of decision, but see David Bailey, Reinvigorating the Role of Article 101(3) under Regulation 1/2003 (2016) 81 Antitrust Law Journal 111. In practice, therefore, competition agencies may be more likely to deal with object restraints which they consider to be "unproblematic" from a competition perspective by deciding not to prioritize it for enforcement.

170 Case 56/65, STM [1966] ECR 235, 249.

171 Case C-501/06 P, GlaxoSmithKline note 144, para. 58.

${ }^{172}$ Case C-67/13P, $C B$ note 141. For a discussion of the implications of the decision, see Bernard Amory et al., The Object-Effect Dichotomy and the Requirement of Harm to Competition: On the Road to Clarity after Cartes-Bancaires?, in THE NOTION OF RESTRICTION OF COMPETITION 65 (Damien Gerard et al. eds., 2017). 
market analysis is required to assess the impact of the agreement, for example, cases involving complex measures, cases where experience ${ }^{173}$ with the restraint is limited or cases where there is a plausible efficiency justification for the conduct. ${ }^{174}$ In these latter situations, negative effects cannot be considered so likely to make assessment of effects redundant. ${ }^{175}$

\section{Established restraints liable in principle to restrict competition by object}

Despite the flexible nature of the characterization exercise described above, over the years EU case-law has established that certain restraints are liable in principle to restrict competition by object. Unsurprisingly, these include cartel agreements ${ }^{176}$ - in particular horizontal collusion to fix prices, limit output, share markets or rig bids, to reduce capacity (see $B I D S^{177}$ ), and/or designed, directly or indirectly, to fix purchase or selling prices through exchanges of information (see T-Mobile Netherlands $B V v$ Raad van bestuur van de Nederlandse Mededingingsautoriteit). ${ }^{178}$ In $C B$ the CJ explained that as such agreements may "be considered so likely to have negative effects, in particular on the price, quantity or quality of the goods and services, that it may be considered redundant, for the purposes of applying Article [101(1)], to prove that they have actual effects on the market..." (emphasis added). ${ }^{17}$

More controversial have been the consistent rulings that certain restraints in vertical agreements also constitute, in principle, restrictions by object even though they are not made between competitors, but between providers of complementary goods and services, and that all such agreements, depending on the environment in which they are concluded, provide scope for efficiencies. ${ }^{180}$ These include vertical price fixing (RPM), ${ }^{181}$ restraints conferring absolute territorial protection (ATP) on a distributor (or otherwise aimed at partitioning national markets or limiting parallel trade), ${ }^{182}$ bans on online selling (which reduces the ability of a distributor to sell outside its territory, see Pierre Fabre ${ }^{183}$ ) and certain selective

173 The importance of experience was also stressed by the CJ in Case C-286/13 P, Dole note 166, para. 115. See also the Opinion of Wathelet AG in Case C-373/14, Toshiba Corp v. Commission EU:C:2015:427.

${ }^{174}$ See e.g., Case C-238/05, Asnef-Equifax, Servicios de Información sobre Solvencia y Crédito, SL v. Asociación de Usuarios de Servicios Bancarios EU:C:2006:734.

175 See also Case C-345/14, SIA “Maxima Latvija”v. Konkurences padome EU:C:2015:784, para 22.

176 See e.g. Case C-373/14 P, Toshiba Corp v. Commission EU:C:2016:26, Case C-172/14, ING Pensii v. Consiliul Concuretnei EU:C:2015:484 and statement of GC in Cases T-374, 375, 384, and 388/94, European Night Services $v$. Commission [1998] ECR II-3141, para 136.

177 Case C-209/07, [2008] ECR I-8637.

178 Case C-8/08, note 166, paras 36-43.

179 Case C-67/13P, $C B$ note 141, para 51.

180 "Most vertical restraints can increase or decrease welfare, depending on the environment. Legality or illegality per se thus seems unwarranted", J. Tirole, THE THEORY OF INDUSTRIAL ORGANIZATION (MIT Press, 1988), 186.

181 See especially, Case 161/84, Pronuptia de Paris v. Schillgallis [1986] ECR 353, at para. 25 and Case 243/83, SA Binon \& Cie $v$. SA Agence et Messageries de la Presse [1985] ECR 2015, at para. 44.

182 See Cases 56 and 58/64, Établissements Consten S.à.R.L. \& Grundig-Verkaufs-GmbH v Commission (Consten and Grundig) [1966] ECR 299 and also eg, COMP/28.282, The Distillers Company Ltd [1978] OJ L50/16, Case 30/78, Distillers Company v. Commission [1980] ECR 2229, COMP/30.228, Distillers Company plc (Red Label) [1983] OJ C245/3; Case T-77/92, Parker Pen v. Commission [1994] ECR II-549.

183 Case C-439/09, EU:C:2011:277. 
distribution systems (SDSs). ${ }^{184}$ In these judgments the Court has not explicitly warned, as it did in $C B$, of a high probability of negative effects on prices etc. They have, however, displayed a suspicion of these acute restraints on rivalry between dealers (given the "considerable impact of distribution costs on the aggregate cost price" ${ }^{185}$ ) and have clearly articulated concern about their impact on the single market project, through prohibiting or limiting the opportunities for parallel or cross-border $\operatorname{trade}^{186}$ and perpetuating price differences ${ }^{187}$ between Member States. Indeed, the Commission has stressed that companies should not ordinarily be allowed to create barriers to trade between Member States, to seal off territories "hermetically ..., making interpenetration of national markets impossible" "188 and so contribute to the cost of "not realising" the EU's single market objectives. ${ }^{189}$

In categorizing limitations on intrabrand competition as restrictions of competition irrespective of the degree of interbrand competition on the market, the EU approach diverges significantly from that adopted by the US Supreme Court in Sylvania and Leegin. ${ }^{190}$ Although it could be argued, as the Supreme Court did, that neither theory nor experience justifies an assumption of anticompetitive effects in these cases, the entrenched nature of the EU caselaw and the seeming concerns about the internal market underpinning it, make a dramatic reversal in this "starting" point seem unlikely. Although there is no formal system of precedent in the EU, the CJ strives for consistency, ${ }^{191}$ generally preferring to develop the law on an incremental basis rather than through sharp changes in policy.

\section{The importance of context in identifying the object or purpose of the agreement:} characterization

It is important to remember, however, that because of the importance of both content and context in identifying the objective of an agreement, the "established" restraints set out above do not constitute a definitive list of object restraints. Numerous cases have thus reached the EU Courts in recent years on the scope of the object category and expressing concern that EU decision-takers have been both (i) too unwilling to accept that the context of a case might demonstrate that an agreement incorporating an established restraint does not have a

${ }^{184}$ Id. A SDS restricts the number or type of dealers that the manufacturer will deal with and prohibits sales from authorized to non-authorized distributors

185 Cases 56 and 58/64, Consten and Grundig note 182, 342-343.

186 Case C-501/06 P, GlaxoSmithKline note 144, para. 59.

187 The Commission is concerned in particular that RPM is generally liable to restrict competition in a number of different ways in particular: through facilitating collusion between suppliers and enhancing price transparency; by eliminating intrabrand price competition; by softening competition between suppliers and/or retailers; by preventing distributors from lowering sale prices; by lowering pressure on manufacturers" margins; by foreclosing competitors; and by reducing dynamism and innovation at the distribution level), Guidelines on Vertical Restraints ("Vertical Guidelines") [2010] OJ C130/10, para 224.

188 Ninetendo [2004] OJ L255/33, para. 338 (thereby bringing to nought economic integration).

189 Commission, Green Paper on Vertical Restraints in EC Competition Policy, COM(96)721, para. 78 ("The elimination of barriers to trade may not achieve its objective if producers and/or distributors introduce practices contrary to integration.”)

190 See notes 97 and text.

191 See e.g., Anthony Arnull, Owning up to Fallibility: Precedent and the Court of Justice (1993) 30 CMLRev 247. 
restrictive purpose; ${ }^{192}$ and (ii) too willing to rely on context to expand the category to "new" restraints. ${ }^{193}$ In $C B,{ }^{194}$ for example, the CJ had to consider whether the Commission and GC had been correct to find that horizontal cooperation, argued to be designed to ensure the success of the carte bleu system in particular through combating free-riding and balancing issuing/acquisition activities, was restrictive by object. ${ }^{195}$ The CJ considered that, given the complex nature of the market and the efficiency justifications raised, negative effects could not be considered so likely to make assessment of effects redundant. ${ }^{196}$ Similarly, some cases have held that agreements incorporating severe restraints on the core parameters of competition will not restrict competition by object (or at all) if designed to achieve a legitimate public policy objective or regulatory aim. ${ }^{197}$

It seems clear, therefore, that horizontal cooperation agreements, with the potential to have mixed effects on competition, should not generally fall within the object category even if containing established restraints. Indeed, the Commission's Horizontal Cooperation Guidelines ${ }^{198}$ recognise that research and development (R\&D), production, and joint purchasing agreements which contain price or output restraints will only restrict competition by object if they do not truly concern, respectively, joint $R \& D$, production, or joint purchasing, but serve as a tool to engage in a disguised cartel. ${ }^{199}$ This approach, focussing on experience and context as well as content to characterise an agreement, ${ }^{200}$ bears close resemblance to the "ancillary restraints" doctrine utilised by the US courts to distinguish per se restraints from restraints that have to be analysed under the rule of reason. ${ }^{201}$

Case-law makes it clear that a similar exercise is also required in relation to vertical agreements. In Murphy, ${ }^{202}$ the CJ accepted that a broadcasting licensing agreement

192 See e.g., Case C-373/14 P, Toshiba note 176 and Cases C-403 and 429/08, Premier League Ltd v. QC Leisure and Murphy v. Media Protection Services Ltd EU:C:2011:631.

193 See e.g., Case C-67/13P, CB note 141, and Case C-345/14, Maxima Latvija note 175.

${ }^{194}$ Case C-67/13P, CB note 141.

195 The CJ referred the matter back to the GC which found that the Commission had correctly established that the agreement had as its effect the restriction of competition and that the agreement did not satisfy the conditions of Art 101(3) - the free-riding arguments had not been substantiated, Case T-491/07, EU:T:2016:379.

196 See also Case C-345/14, Maxima Latvija note 175, para 22.

197 See Case C-309/99, Wouters v. Algemene Raad van de Nederlandse Orde van Advocaten [2002] ECR I1577, paras. $106-110$ and note 237 and text.

198 See Horizontal Cooperation Guidelines [2011] OJ C11/1, paras 128, 160-161, and 205-206, Esteva Mosso, note 15 (object restrictions have no equivalent in merger analysis rather each merger is analysed to determine its likely impact of the merger on the main market parameters of competition).

199 See note 198.

${ }^{200}$ Such an approach is also in line with that adopted in merger cases. No merger transactions are assumed to significantly impede effective competition. Rather, because it is assumed that mergers offer scope for efficiencies, a range of relevant factors, not just a contractual clause in isolation, are analysed to determine the likely impact of the merger on the main parameters of competition (price, output, quality, innovation, etc.).

${ }^{201}$ Under this approach, the initial inquiry as to whether the restraint is ancillary is distinct from the substantive rule of reason analysis conducted; the fact that it is ancillary to legitimate joint activity is not therefore enough to establish as a matter of law that the agreement does not unreasonably restrain trade and so falls outside Section One, see especially note 81 and text.

${ }^{202}$ Cases C-403 and 429/08, note 192, para 139 
containing territorial limitations aimed at partitioning national markets, would not be regarded as restrictive by object where other circumstances falling within its economic and legal context justified the finding that such an agreement is not liable to impair competition and in Pierre Fabre ${ }^{203}$ the CJ held that a selective distribution agreement incorporating a ban, or de facto ban, on internet selling necessarily restricted competition (and restricted competition by object) unless objectively justified (it constituted a proportionate measure to achieve a legitimate aim).

Although the cases thus demand contextual analysis in the characterization process, a difficulty lies in the way that such assessments have been in practice. In many cases parties' arguments relating to experience or context in cases involving established restraints are given short shrift. Not only is jurisprudence governing horizontal cooperation agreements and joint ventures in this area somewhat unpredictable, ${ }^{204}$ but there is no case involving an ordinary vertical agreement (rather than an intellectual property (IP) licensing agreement ${ }^{205}$ ) in which the Commission (or Court) has been prepared to accept, on the facts, that either ATP or RPM is not restrictive of competition by object. Rather, as is illustrated by the 1966 case of Établissements Consten S.à.R.L. \& Grundig-Verkaufs-GmbH v Commission (Consten and Grundig), ${ }^{206}$ in these cases the focus tends to be on the restraints imposed and it seems simply to be assumed that they are unnecessary or disproportionate to any objective pursued. An acute concern therefore is that the object category in the EU is overinclusive.

\section{"New" object restraints}

Also contentious has been the question of whether, and if so when, new restraints can be found to restrict competition by object (for example, multilateral interchange fees (MIFs), most favoured nation clauses, patent settlement agreements, and/or no-poach agreements). Some judgments of the CJ may have encouraged EU competition agencies to push the boundaries of this category, ${ }^{207}$ by utilising over-expansive language suggesting that object characterization might be appropriate in relation to new restraints which are likely to, ${ }^{208}$ capable of having, or have the potential to have, "a negative impact on competition". ${ }^{209}$ As these statements, taken in isolation, seem to extend the category well beyond agreements containing "obvious" restrictions of competition and to blur the line inappropriately between object and effects analysis, the CJ's reminder in $C B$ that the category of object restrictions

203 Case C-439/09, Pierre Fabre note 183.

${ }^{204}$ See e.g., cases COMP/29.373, Visa International-Multilateral Interchange Fee [2002] OJ L318/17, COMP/34.579, MasterCard [2009] OJ C264/8, COMP/39.398, Visa IP/10/1684 and COMP/39.595, Star Alliance: Continental/United/Lufthansa/Air Canada 23 May 2013.

${ }^{205}$ In Case 262/81, Coditel v. Ciné Vog Films (Coditel II) [1982] ECR 3381 the CJ held that an exclusive territorial licence conferring ATP on a broadcaster was not as such restrictive of competition. See also Case 27/87, Erauw-Jacquéry $v$. La Hesbignonne [1988] ECR 1919.

${ }^{206}$ Cases 56 and 58/64, Consten and Grundig note 182.

207 See e.g., the Commission's decision in COMP/39.612, Périndopril (Servier) 9 July 2014, IP14/799, on appeal Case T-691/14, Servier SAS v Commission (judgment pending) and the UK (then) OFT's decision in Tobacco 15 April 2010, decision quashed Case Nos 1160-1165/1/1/10 Imperial Tobacco Group plc \& Ors V OFT [2011] CAT 41.

208 Case C-32/11, Allianz Hungária Biztosító Zrt, Generali-Providencia Biztosító Zrt v. Gazdasági Versenyhivatal EU:C:2013:160.

${ }^{209}$ Case C-8/08, T-Mobile note 166, 
should be interpreted restrictively and confined to agreements which evidently harm the proper functioning of competition is to be welcomed. ${ }^{210}$

\section{Rules or Presumptions of Legality?}

It has been seen that providing a rule of legality or a safe harbour can be a useful mechanism for immunising, and so encouraging, certain behaviour which is most unlikely to be anticompetitive and likely to produce desired benefits. In the EU, the CJ has, for example, excluded from Article 101 both agreements designed to improve working conditions (where the application of the competition laws would thwart achievement of another Treaty objective $^{211}$ ) and agreements which do not "appreciably" restrict competition. The latter cases make it clear that EU law is not concerned with agreements which have an "insignificant effect on the market, taking into account the weak position which the persons concerned have on the market of the product in question". ${ }^{212}$ Although there seems no reason in principle why even agreements incorporating object restraint should not fall outside Article 101(1) on de minimis grounds, the CJ's 2011 judgment in Expedia ${ }^{213}$ is being widely interpreted as holding that such agreements always infringe Article 101(1) - they are simply assumed to restrict competition appreciably. ${ }^{214}$

The EU system also utilises BERs, for example, for research and development, specialisation, vertical and technology transfer agreements, as central mechanisms for "exempting" categories of agreements from Article 101(1). Most BERs since modernization ${ }^{215}$ apply only if specified conditions are met: in particular, that market share thresholds (used as rough proxies for market power) are not exceeded and "hard-core" restraints are not incorporated within the agreements. As the benefit of these regulations, which are directly applicable, can only be withdrawn prospectively, ${ }^{216}$ they provide comfort to firms that agreements satisfying their conditions are compatible with Article 101 on the grounds that that the efficiencies resulting from the agreement are presumed to offset any anticompetitive effects. The ability to withdraw the BERs means, however, that Article 101 can be applied in the future to agreements which are proved to infringe Article 101.

${ }^{210}$ In Case T-472/13, Lundbeck v. Commission EU:T:2016:449 the GC concluded that the Commission had rightly concluded that patent settlements involving reverse payment were akin to market exclusion agreements liable to have negative effects on competition, so it was unnecessary to demonstrate that they had such effects for the purpose of Art 101(1).

${ }^{211}$ Case C-67/96, Albany International BV v. Stichting Bedrijfspensioenfonds Textielindustrie [1999] ECR I5751 it excluded entirely from the scope of Art 101 collective agreements between workers and employers intended to improve working conditions (the Treaty objective of achieving a high level of employment and social protection would be thwarted if Art 101 applied to them). Agreements concluded by firms carrying out tasks of a public or social nature also fall outside of Art 101. See also the agricultural exemption, Reg. 1184/2006 [2006] OJ L214/7 and Reg. 1308/2013 [2013] OJ L347/671.

212 Case 5/69, Völk v. Vervaecke [1969] ECR 295, 302

${ }^{213}$ See Case C-226/11, Expedia Inc v. Authorité de la concurrence EU:C:2012:795 and De minimis notice, id.

${ }^{214}$ Notice on agreements of minor importance which do not appreciably restrict competition under Article 101(1) of the Treaty on the Functioning of the European Union (De Minimis Notice), C(2014) 4136 final

215 See note 159 and text.

${ }^{216}$ Reg 1/2003 [2003] OJ L1/1, Arts 29(1)(2) and e.g., Reg. 330/2010 [2010] OJ L, recital 15 (see also Art. 6). Where the BER appears to exempt an agreement which is problematic, the Commission or NCA have to withdraw its benefit from the agreement which is valid and compatible until then (consequently no infringement decision of fine for breach is possible). 
It has been mentioned already that one problem with the BERs is that even though (i) in line with a consumer welfare objective, they are less rigid and formalistic than their predecessors, and (ii) they provide valuable legal certainty, they do create some conceptual difficulties within the Article 101 analytical framework. One issue is that they focus analysis on Article 101(3) rather than Article 101(1). For example, the Commission's Vertical Guidelines acknowledge that for "most vertical restraints, competition concerns can only arise if there is insufficient competition at one or more levels of trade, i.e. if there is some degree of market power at the level of the supplier or the buyer or at both levels". ${ }^{217}$ Further, that even agreements between parties whose market shares exceed the 30 per cent market share threshold set out in the BER for vertical agreements, Regulation 330/2010, ${ }^{218}$ may not infringe Article 101(1). The Guidelines offer no explanation, however, as to why such a broad overarching block exemption is necessary at all for agreements concluded between parties which lack market power and which do not contain hard-core restraints (most or many of which seem unlikely to infringe Article 101(1)). Secondly, their refusal to accept that agreements incorporating hard-core restraints may be block exempted means that the economic logic underpinning them has not been pushed as far as some might like.

\section{E. Developing Standards: Individual "Effects" Analysis under Article 101(1) and Article 101(3)}

\section{i. Overview}

Because of the substantial reliance on both the category of object restraints (by the Commission, and NCAs, in their infringement decisions) and the de minimis principle and BERs (by firms), the question of how antitrust analysis is conducted in other scenarios arises relatively rarely before the EU courts and so is comparatively unexplored. There is therefore no steady flow of cases emerging before the EU courts which allows them to develop and hone the case-law in this area. The cases that do exist arise either result from: (a) an Article 267 reference made by a national court (in these cases the CJ is asked to advise only on the interpretation of Article 101 leaving the national court to apply that interpretation to the facts of the case in front of it); or (b) a request to review a Commission decision taken under Article 101(1) and (3) (since the abolition of the notification and authorisation system set up by Regulation 17 fewer of these cases are arising as Article 101 "effect" cases examined by the Commission tend to be resolved through commitments, rather than final, decisions ${ }^{219}$ ). The sections below examine the existing case-law and considers how it guides detailed appraisal of agreements under Article 101.

\section{ii. Article 101(1) - identifying agreements with restrictive effects}

The case-law sets out some important starting principles relevant for analysing restrictive effects under Article 101(1). For example, it clarifies that: Article 101 is concerned both with restrictions of competition between the parties and between a party/ and third parties; ${ }^{220}$ it is necessary to examine an agreement in its market context to determine its effects (whether

\footnotetext{
217 Vertical Guidelines, para. 6.

218 [2010] OJ L102/1.

219 See e.g., COMP/39.595, Star Alliance note 204.

${ }^{220}$ Cases 56 and 58/64 Consten and Grundig note 182.
} 
alone or in combination with other agreements) ${ }^{221}$ the analysis should be conducted in the light of the competition which would occur if the agreement in question had not been made; ${ }^{222}$ and even where an assessment is being made ex post, demonstration of actual or likely ${ }^{223}$ effects is sufficient. The cases thus confirm that "not every agreement ... which restricts the freedom of action of the parties or one of them necessarily falls within the prohibition"; ${ }^{224}$ account has to be taken of the actual condition, and economic context, in which the agreement functions. ${ }^{225}$

Some judgments of the EU courts, for example, the CJ's judgment in Delimitis, ${ }^{226}$ support the view that the Article 101(1) inquiry must focus on the important question whether or not the agreement, alone or in conjunction with a network of similar agreements, would be likely to have an appreciable impact on the parameters of competition (such as price, quantity or quality) ${ }^{227}$ and allow the parties to exercise market power - in that case through a restriction of interbrand competition. In Delimitis the Court set out guidance for a national court as to how to assess the compatibility with Article 101(1) of a beer supply agreement obliging a café proprietor to purchase most of its beer requirements from the brewer. In so doing, it stressed the importance of assessing whether the agreement appreciably contributed to a foreclosure of access to the market. This required the relevant market to be defined and an assessment made of whether there was a concrete possibility for new competitors to penetrate the market or existing competitors to expand. Similarly, in $\mathrm{O} 2$ (Germany) $\mathrm{GmbH} \& \mathrm{Co} O H G$ $v$ Commission ${ }^{228}$ the $\mathrm{GC}$ stressed, in the context of horizontal cooperation, that the Article 101 analysis consists essentially in taking account of the impact of the agreement on existing or potential competition and the competitive situation in the absence of the agreement. Further, in European Night Services ${ }^{229}$ the GC referred to the need to take account of the economic context in which the undertakings operate, the products or services covered by the agreement, the actual structure of the market concerned and the conditions of competition, including existing and potential competition, to determine whether there were real concrete possibilities for the undertakings concerned to compete among themselves or for a new competitor to penetrate the relevant market and compete with established undertakings.

Not all of the Article 101case-law is, however, easy to fit within the (economic) structure envisaged by the Commission. Rather, some cases have rejected the need for a necessary link

${ }^{221}$ Case 56/65, STM note 170. Case C-382/12 P. MasterCard and Others v. Commission EU:C:2014:2201, para 165 ("when appraising the effects of coordination between undertakings in the light of Article [101], it is necessary to take into consideration the actual context in which the relevant coordination arrangements are situated, in particular the economic and legal context in which the undertakings concerned operate, the nature of the goods or services affected, as well as the real conditions of the functioning and the structure of the market or markets in question").

222 Case 56/65 id.

223 " [A] cording to the settled case-law of the Court, Article 101(1) TFEU does not restrict such an assessment to actual effects alone, it must also take account of the potential effects of the agreement or practice in question on competition", Case C-345/14, Maxima Latvija note 175, para 30.

224 Case C-309/99, Wouters note 197, para 97.

${ }^{225}$ Case T-112/99, Métropole Télévision SA (M6) v. Commission [2001] ECR II-2459.

${ }^{226}$ Case C-234/89, Delimitis v. Henninger Bräu [1991] ECR I-935.

227 See e.g., Case C-382/12 P. MasterCard note 221, para 93.

${ }^{228}$ Case T-328/03, [2006] ECR II-1231, para. 71.

${ }^{229}$ Cases T-374, 375, and 388/94 note 176, para. 136. 
with consumer harm when identifying a restriction of competition, demanding only harm to competition or the competitive structure ${ }^{230}$ and some, as is seen below, suggest that "public policy" factors are relevant in assessing both whether there is a restriction of competition within the meaning of Article 101(1) ${ }^{231}$ and whether it produces benefits at the Article 101(3) stage. $^{232}$

Further, in a line of cases frequently referred to in the EU as "ancillary restraints cases" the EU Courts, as explained in Remia \& Nutricia, ${ }^{233}$ consider what the state of competition would be if certain allegedly restrictive clauses did not exist. If it is found that individual restraints contained in a non-restrictive transaction are objectively necessary for, directly related and proportionate to it - i.e. without it the transaction (in that case the sale of a business together with its goodwill) would be unlikely to be implemented or proceed - it holds that they "are free of the prohibition of Article 101(1)". ${ }^{234}$ In these cases, the restraints, even if they do restrict competition, fall outside Article 101(1) as, without them, the beneficial transaction would not take place. If the clauses are not found to be ancillary, however, it seems that they are not prohibited automatically but only if established to restrict competition - whether by object or effect ${ }^{235}$ (see also Pronuptia de Paris GmbH v Pronuptia de Paris Irmgard Schillgallis ${ }^{236}$ where the CJ made it clear that restraints in the franchising agreement which were not considered to be ancillary to it had to be scrutinised to see if they restricted competition).

In an analogous way, the $\mathrm{CJ}$ has also held that a "restraint" in an agreement will not infringe Article 101(1) if it could reasonably be considered necessary to ensure a public policy objective, such as the proper practice of the legal profession. ${ }^{237}$ Similarly, in a line of cases dealing with vertical and IP licensing agreements the Court has tended to assume that "restraints" on distributors/licensees competing with each other ${ }^{238}$ (restraints on intrabrand competition) are restrictive of competition ${ }^{239}$ unless necessary to achieve some identified,

${ }^{230}$ But see notes 141-144 and text.

231 See note 197 and text.

232 See note 252 and text.

${ }^{233}$ Case 42/84 [1985] ECR 2545. The doctrine as envisaged by Remia thus seems to have two distinct parts: the non-compete clauses or other restrictions must be objectively linked to the main transaction so that they are assessed together; and the main transaction must be compatible with Art 101.

${ }^{234}$ In Remia ibid it was held that a non-competition clause, reasonably limited in time and scope, would be ancillary to the sale of the business as without it the vendor could win back the custom from the purchaser. Such clauses could, therefore, enhance competition by increasing the number of undertakings on the relevant market. This will, however, exclude only certain clauses from Art 101(1). See also Art 101(3) Guidelines, para. 28 ("If ... it is concluded that the main transaction covered by the agreement is not restrictive of competition, it becomes relevant to examine whether individual restraints contained in the agreement are also compatible with Article [101(1)] because they are ancillary to the main non-restrictive transaction").

${ }^{235}$ Case C-382/12 P. MasterCard note 221.

${ }^{236}$ Case 161/84, [1986] ECR 353.

${ }^{237}$ In e.g., Case C-309/99, Wouters note 197, the CJ clarified that there would be no infringement of Art 101(1) where a restrictive provision with an adverse effect on competition could be considered necessary to ensure that consumers and the sound administration of justice were provided with necessary guarantees in relation to integrity and experience.

${ }^{238}$ It has been seen that in these cases the EU courts have been inherently suspicious of restraints on rivalry between dealers

${ }^{239}$ See Cases 56 and 58/64, Consten and Grundig note 182 and Case C-439/09, Pierre Fabre note 183. 
legitimate purpose. ${ }^{240}$ These restraints are thus held to be restrictive of competition unless it is shown that they are necessary for example: to facilitate the penetration of a new market by an undertaking through the prevention of free riding on a dealer's marketing and promotion efforts (see, for example, Société Technique Minière v Maschinenbau Ulm GmbH (STM)); ${ }^{241}$ to encourage investment by a licensee, ${ }^{242}$ or to encourage non-price competition between dealers in a SDS (see, for example, Metro-SB-Grossmärkte GmbH v Commission (Metro $\left.1)^{243}\right){ }^{244}$

These strands of cases, developed from early jurisprudence (and before modernization), display slightly different nuances, without fully clarifying their relationship with each other and/or their implications for Article 101(1) and Article 101(3) analysis more generally. It is clear, nonetheless, that each involve both some form of characterization exercise and some form of truncated analysis and burden shifting in the identification of restrictions of competition. The ancillary restraint cases assess first whether the restraints seem necessary to the legitimate agreement/ objective - if this seems plausible they are not considered to be restrictive of competition by object. Second, the restraints are tested to see if they are ancillary. If they are necessary, they fall outside of Article 101(1) altogether - it seems to be assumed that the legitimate objective pursued outweighs any restrictions which flow from the restraints identified. Thirdly, if they are not ancillary, a fuller analysis of the agreement's restrictive effects (under Article 101(1)) and countervailing benefits (under Article 101(3)) is required. In objective necessity cases, in contrast, the objective necessity function seems to perform only a combined classification and truncated analysis function. If the restraints are not objectively necessary they are assumed to restrict competition (they are restrictive of competition by object). If they are objectively necessary however they do not restrict competition (by object or effect).

The analysis conducted in these cases does not therefore demand an assessment of the agreement's actual or likely effects on competition and the extent to which a negative effect on prices, output, innovation, or the variety or quality of goods and services can be expected nor a detailed examination of the offsetting efficiencies/ benefits. Further, although in some cases the EU courts have gone out of their way to stress that that they do no conduct a USstyle rule of reason, the appraisal conducted in each does involve some loose form of balancing or consideration of the agreements benefits raised by the defendant against harms at the Article 101(1) stage, the very analysis that the Commission states is reserved for Article 101(3). Indeed, in some cases the balancing conducted under Article 101(1) is closely in line with the type done in free movement cases using the "EU rule of reason". ${ }^{245}$ Finally,

\footnotetext{
${ }^{240}$ See Cases C-403 and 429/08, Murphy note 192.

${ }^{241}$ Case 56/65, STM note 170.

${ }^{242}$ Case 258/78, Nungesser and Eisele v. Commission [1982] ECR 2015

${ }^{243}$ Case 26/76, [1977] ECR 1875, para. 21 and see Art 101(3) Guidelines, para 24.

${ }^{244}$ See also Vertical Guidelines, para 61 (in the case of ATP, stating that such restraints will fall outside Art 101(1) for two years where a manufacturer needs to encourage substantial investments by a distributor in order to start developing a market). Bizarrely, the Guidelines contain no similar statement in relation to RPM, suggesting (without explanation) that the Commission does not envisage circumstances in which it could be held that a procompetitive objective pursued, might warrant a finding that RPM does not restrict competition by object. The Guidelines do accept, however, that in exceptional circumstances RPM might generate efficiencies cognisable under Art 101(3)).

${ }^{245}$ See eg Cases C-403 and 429/08, Murphy note 192 and Case C-309/99, Wouters note 197. In the EU restrictions on free movement are found to be incompatible with EU law unless it can be shown that the
} 
the cases do not provide clear guidance as to how it can be determined whether a restraint is objectively necessary or directly related, necessary and proportionate to an agreement or what the counterfactual is. ${ }^{246}$ Rather the jurisprudence itself accepts that this constitutes a rather "abstract" exercise, and the thresholds set are high.

\section{iii. Article 101(3)}

Although modern guidance on how Article 101(3)'s elements are to be interpreted is sparse, it is clear that the burden is on the parties to show that it is more likely than not that all four of its (cumulative and onerous) conditions are satisfied ${ }^{247}$ and that any agreement may in principle satisfy the criteria. ${ }^{248}$ Further, that benefits resulting from Article 101(3) must result not just to the parties (in their production and distribution activities) but must create appreciable objective advantages to compensate consumers for the disadvantages which they cause in the field of competition. ${ }^{249}$ It is, however, the beneficial effect on all consumers in the relevant markets that is relevant, not the effect on each member of the category. ${ }^{250}$

One controversy is whether Article 101(3) only allows for efficiency justifications to be raised. Although some early jurisprudence indicates that other non-competition factors are cognizable under Article 101(3), ${ }^{251}$ one view is that even if this position may have been supportable in a system where Article 101(3) decisions were made by a sole-decision taker (pre-2004, the Commission), it is not appropriate that, in the current decentralised enforcement systems, NCAs and national courts should also be able to conduct this type of balancing exercise between competition and non-competition factors. The Commission thus states in its Guidance that public policy factors are relevant only if they can be used to supplement the economic benefits which the agreement generates. This point has, however, yet to be explicitly addressed by the EU Courts. ${ }^{252}$

A particularly difficult hurdle for those relying on Article 101(3) to overcome is the "indispensability" criterion. In contrast to the ancillary restraints doctrine, this is stated to require not a showing that the agreement would not be concluded in the absence of the restrictions but that the restrictions are indispensable to the achievement of the benefits, while allowing consumers a fair share of them. ${ }^{253}$ Restrictions are not indispensable, therefore, if

measure (i) is justified either on the basis of one Treaty-based exceptions or the Court-recognised justifications - the overriding requirements of public interest (the EU rule of reason) and (ii) proportionate.

${ }^{246}$ Especially as, as has been seen RPM and ATP are almost never considered to be required to achieve a legitimate purpose such as the penetration of a new market and the elimination of free-riding, see

${ }^{247}$ See note 152 . Contrast the position in the US, where the burden on the defendant is not so onerous see Section 3.E.

248 Including agreements containing object restraints but see note 169 and text.

${ }^{249}$ Case C-382/12 P, MasterCard note 221 and Case T-111/08, MasterCard EU:T:2012:260

${ }^{250}$ Case C-238/05, Asnef-Equifax note 174, para. 70.

251 See e.g., Cases T-528, 542, 543, and 546/93, Métropole Télévision SA v. Commission [1996] ECR II-649.

${ }^{252}$ In Cases C-403 and 429/08, Murphy note 192 the applicant did raise a number of arguments, to justify its exclusive broadcasting licensing arrangements under Art 101(3), including that the arrangements encouraged the public to attend football games. In line with the conclusions the CJ reached in relation to the free movement provisions, however, the CJ cursorily rejected the justifications, but without stating whether the non-competition benefits were in fact relevant under Art 101(3)

${ }^{253}$ Case C-382/12 P. MasterCard note 221 para 93 and Art 101(3) Guidelines, para. 74. 
efficiencies can be achieved by other practicable or less restrictive means ${ }^{254}$ or if they are not reasonably necessary to produce the efficiencies. This criterion seems to incorporate a "sliding scale", ${ }^{255}$ meaning that it harder for more severe restraints (especially by object ones $^{256}$ ) to satisfy it.

\section{F. Summary and the Impact of the Enforcement System}

The EU enforcement structure has had a significant, and enduring, influence on the substantive interpretation of Article 101's provisions. The initial centralised system in which the Commission had the exclusive right to apply Article 101(3) individually to agreements created a temptation for the Commission to apply Article 101(1) formalistically and place emphasis on Article 101(3) as the main vehicle for authorising agreements. As, pre-2004, obtaining an Article 101(3) exemption was not easy in practice, the ancillary restraints and objective necessity doctrines (along with development of the de minimis principle and the adoption of BERs) provided mechanisms for ensuring some restraints on freedom of action could escape from the Article 101(1) prohibition. Although the modernization process promised a decentralised enforcement system and more realistic assessment of agreements under Article 101(1), it has been seen that there is still emphasis on object restraints in the cases, the jurisprudence on how "effects" analysis is to be conducted under Article 101(1) (or efficiencies assessed under Article 101(3)) has not evolved significantly and BERs continue to play a central role in the system. These products of the old system have endured but are difficult to rationalise within the modernized framework creating overlaps with, and confusion as to, the analysis to be conducted under Article 101(1) and Article 101(3) - in particular how exactly ancillary restraints and objective necessity inquiries under Article 101(1) differ from examination of indispensability within the forum of Article 101(3).

The decentralised enforcement system, together with the Commission's policy of imposing significant fines on undertakings that have committed serious infringements, may also be factors which encourage reliance on brighter line rules which promote certainty and consistency in decision-taking.

\section{Conclusions}

This paper recognises that the contours of an antitrust analytical framework must be moulded to fit each individual competition regime taking account of range of factors, including the objectives and make up of its rules, the maturity of the regime and way in which it is enforced. Nonetheless, this paper finds support for a number of broad propositions:

- The legal system cannot always replicate the principles underpinning it meaning that legal commands may create risks of Type 1 or Type 2 errors;

- The modern progression in antitrust analysis is - for agreements, single-firm conduct and mergers - from categories to concepts, with the use of presumptions and burden shifting to organize the application of the concepts;

- Carefully confined rules, or strong presumptions, of illegality and legality may be desirable to deter manifestly anticompetitive conduct and to promote or encourage procompetitive behaviour respectively. However, excessive use of bright line rules to condemn risks Type I errors and invites equilibration to evade them;

\footnotetext{
${ }^{254}$ Case C-68/12, Protimonopolný note 152.

255 Faull \& Nikpay note 1553.494.

256 See note 168 and text.
} 
- The need for clear rules in criminal enforcement, cases resulting in civil penalties/fines or decentralised enforcement systems may require certain agreements to be dealt with through a dichotomy model rather than a continuum model;

- Characterization mechanisms are required to minimise Type 1 errors and distortions flowing from the application of (otherwise) overinclusive rules or presumptions of illegality (systems must provide flexibility to assess efficiency claims at the preliminary stage of analysis in all cases);

- Various strands of analysis dealing with ancillary restraints, less restrictive alternatives and balancing of competitive harms and benefit in the US and EU require integration within a coherent framework;

- If meritorious antitrust actions are not to be deterred, courts and agencies must endeavour to provide structured and clear guidance as to how competitive harms and benefits can be weighed or balanced against each other in cases where detailed analysis of the effects of an agreements is required; and

- Administrative adjudication may provide an effective device for elaboration of doctrine.

In recent years extensive debate has considered whether and if so how to ensure substantive convergence between US and EU antitrust law, in particular in relation to mergers and singlefirm conduct. Although relatively little attention has focussed on agreements the discussion in this paper illustrates that there is still significant divergence between the US and EU systems in this area.

In the US there has, in the last forty years, been a distinct shift away from a dichotomous approach to antitrust analysis of agreements towards one based on a continuum. Although criminal enforcement has supported retention of a per se rule in relation to a narrow category of horizontal cartel cases, in every case a classification process provides the defendants with the opportunity to raise an "efficiency" story for its agreement before it can be condemned as illegal per se. Agreements with a plausible efficiency rationale are analysed under the rule of reason, although not every case is a candidate for plenary analysis. Rather truncated analysis, involving burden shifting between the parties, may be carried out in some situations. It is in the area of rule of reason where greater elaboration of policy is required and where there is a need for greater clarification on the questions of which party bears the burden of proof or production and when and how it can be determined whether less restrictive means of achieving a procompetitive objective exist and/or whether anticompetitive effects outweigh the procompetitive effects of the agreement (or vice versa). For all of the effort that the courts have taken to clarify the rule of reason and its application to restrictive agreements, considerable room remains to integrate various strands of analysis (including ancillary restraints doctrine) into a single, coherent framework

Experience also has focused attention on the institutional arrangements for refining doctrine. In a number of cases, the FTC's administrative adjudication mechanism has supplied the catalyst for improvements in the rule of reason framework. The contributions of cases such as IFD and Polygram suggest the value of FTC's administrative process as means for continued doctrinal clarification and elaboration. This will not likely happen by accident, and further progress will require conscious efforts by the FTC, in cooperation with the Justice Department, to map out the contours of existing jurisprudence and to identify how best to use the FTC's unique capabilities in this regard.

In the EU, although there has recently been a greater acceptance that Article 101, Article 102 and merger analysis should converge around a single analytical framework based on uniform concepts, it has been seen that the system governing agreement in fact continues to rely much more heavily on presumptions of both illegality and legality than in the US and in the EU's 
own dominance and merger frameworks. In consequence, few agreement cases exist in which a balancing of actual or likely restrictions on parameters of competition against efficiencies is actually required.

This paper proposes that EU decision-takers should become more willing to analyse whether theory, experience and especially context justifies a finding that an agreement is restrictive by object. $^{257}$ Up until now, they have been more disposed to have regard to experience and context as a mechanism for expanding the by object category than as a means of narrowing it. To ensure that the object category is not overinclusive, it is essential that it be confined to agreements demonstrating a high likelihood of anticompetitive effects (capability, potential or likelihood of anticompetitive is insufficient) and that it should not be applied in cases where the restraint on competition is not obvious.

If the breadth of the object category is more realistically limited, a claimant will more frequently be required to demonstrate restrictive effects (actual or likely) before the parties can be required to provide a robust justification of the efficiencies within the Article 101(3) forum. ${ }^{258}$ The EU administrative framework provides a flexible forum for the competing effects of agreements to be scrutinised and balanced. If the Commission were to bring more effect cases, resources could be concentrated on developing the Article 101 framework (rather than the limits of the by object category) and clarifying important issues such as the role of the EU ancillary restraints and objective necessity principles. Although these doctrines may have made sense in the pre-modernized era (and when getting an Article 101(3) exemption for an agreement was frequently impractical) and make sense as characterization mechanisms, they are harder to rationalise within a modernized framework which requires economic analysis at both the Article 101(1) and Article 101(3) stage of the assessment. Not only do the cases seem to miss some important steps in competition analysis but they appear to demand inquiries under Article 101(1) which duplicate or overlap with analysis required in the process of applying Article 101(3).

As suggested above, we see a larger purpose for courts and antitrust enforcement agencies in the EU and the US to focus additional attention upon the framework for assessing restrictive agreements. Intense discussions about disparities in how the two jurisdictions treat unilateral conduct seem to eclipse important differences in the evolution of the essential tools for assessing concerted action. Mutual reflection on the different evolutionary paths could deepen understanding about possible doctrinal options and inform improvements in both regimes. This also could be the occasion for a broader examination of how experience across all of the shared areas of competition law - agreements, dominant firm conduct, and mergers - could guide the establishment of a unified analytical framework that ensures that the assessment of all forms of antitrust-relevant conduct is liberated from the need to place behaviour in certain historical categories and instead concentrates upon core concepts

${ }^{257}$ One institution that can contribute to this process is the European Competition Network, which could assist in collecting and examining the experience of the Commission and the NCAs. On the ECN's successes and limitations as a mechanism for convergence within the EU, see Imelda Maher, The Challenge of European Competition Network Convergence in the Definition of Harm to Competition, in The Notion of Restrriction of Competition 87 (Damien Gerard et al. eds., 2017).

${ }^{258}$ Case C-67/13P, $C B$ note 141, para 52 ("Where the analysis of a type of coordination between undertakings does not reveal a sufficient degree of harm to competition, the effects of the coordination should ... be considered and, for it to be caught by the prohibition, it is necessary to find that factors are present which show that competition has in fact been prevented, restricted or distorted to an appreciable extent."). 
involving the presence of actual or likely anticompetitive effects and the existence of valid business justifications. ${ }^{259}$

${ }^{259}$ See Gavil, note 10, at 735 (observing, in the US context, that "the core economic concepts of antitrust provide a common foundation for all antitrust analysis, not just Section 1 of the Sherman Act, with which the rule of reason is most often associated"; adding that these core concepts "have spawned a collection of 'rules of reason' that ... serve as a set of unifying first principles for antitrust law"). 